Arab Univ. J. Agric. Sci., Ain Shams Univ., Cairo, Egypt

28(4), 1225-1244, 2020

Website: http://ajs.journals.ekb.eg

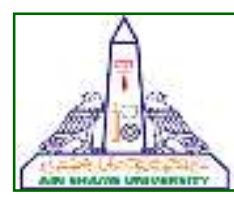

1225

\title{
Synergistic Effect of Some Post-harvest Treatments and Passive Modified Atmosphere Packaging Conditions on Cold Storability of "Canino "Apricot Fruits
}

\author{
Samah I Nasr
}

Higher Institute for Agriculture Co-Operation, P.O. Box 198, Hadayek Shoubra, Cairo, Egypt

${ }^{*}$ Corresponding author: Sama55adel@yahoo.com

Accepted 23 November, 2020

\begin{abstract}
The effect of some post-harvest treatments including salicylic acid (SA), Polyethylene Glycol (PEG) as antioxidants combined with two passive modified atmosphere packaging (MAP) as a supplementary cold storage treatments to extend storability and reduce chilling injury symptoms of Canino apricots (Prunus armeniaca) during storage at $1 \pm 1^{\circ} \mathrm{C}$ for 21 days followed by 5 days at $18 \pm 2^{\circ} \mathrm{C}$ as a marketing conditions simulation, was evaluated during 2018 and 2019 seasons. Physical properties, greatly affected with both factors of study. The great effect in this respect was obtained with $1 \mathrm{mM} \mathrm{SA}$ and $0.4 \%$ PEG plus polypropylene film as type of passive modified atmosphere during cold storage and marketing period. These treatments decreasing discarded \%, chilling injury (scale) and weight loss $\%$, whereas fruit firmness recorded highest values than control Packed apricots by polypropylene film and treated with $0.4 \% \mathrm{PEG}, 1.0 \mathrm{mM} \mathrm{SA}$ and combined treatment of ascorbic and citric acids (1:0.5) significantly preservation fruit quality properties, increased TSS, phenols and carotenoides components and decreased total acidity values, in addition, it reduces the lost in the ascorbic acid content. Also, the mentioned treatments were effective in increasing activity of peroxidase and catalase enzymes reducing electrolyte leakage values and respiration rate. Controlling chilling injury, minimizing electrolyte leakage, respiration rate as well as improve enzymes activity are considered a good indicators to increase storage longevity and high quality. So, it could be suggested that, salicylic acid at $1.0 \mathrm{mM}$ or polyethylene Glycol at $0.4 \%$ and packed With the type of passive modified atmosphere (polypropylene film,) were more effective in reducing
\end{abstract}

fruit quality losses, decay `and keeping quality of "Canino" apricot fruits through cold storage at $1 \pm 1^{\circ} \mathrm{C}$ for 21 days followed by 5 days at $18 \pm 2^{\circ} \mathrm{C}$ as a marketing conditions simulation.

Keywords: Apricot, Salicylic acid, Polyethylene glycol, Ascorbic acid, Cold storage, Passive modified atmosphere packaging

\section{Introduction}

Apricot fruits (Prunus armeniaca) are generally characterized by their worldwide distribution due to their high nutritional benefits, good taste and antioxidant components which are also of great importance as a processed product (Solis-Solis et al 2007). Generally fruit apricot ripening takes place between June and July, it appears in the market in large quantities, for a short periods and quickly Within little days (at room temperature) the fruits become tender with a sharp decrease in quality and this causes a physiological imbalance of fruits (Cao et al 2009) Cold storage is resorted to to prolong the ripening period and thus to control cold damage, but it must be clarified that the apricot fruits are sensitive to low temperatures which exposes them to defects in appearance. (Goto et al 2011).

During cold storage of apricots, damage occurs in the cell membranes, which is represented by an imbalance in the metabolic and physiological processes, the most important of these symptoms is known as cold damage, where the fruits become rough to the touch, with a decrease in juiciness and a disturbance in ripening, which affects the characteristics and marketing value (Koushesh et al 2016). 
It generally uses modified atmosphere packaging (MAP) to minimize respiration rate and water loss, thus prolonging the storage time. Low oxygen and high carbon dioxide atmospheres can extend the marketing lifetime of many commodities (Kader et al 1989). These impacts, were the rationale for delaying the reduction in acidity percentage and to stay up firmness fruit, soluble solids content and Lascorbic acid (Maghenzani et al 2016).

Modified atmosphere packaging's are accomplished by the pre-owned film penetrability and therefore the respiratory rate of fruits and this influence the Writing processes of the cells. The term passive modified packaging is used when the inner atmosphere around the fruits is modified by their respiration. While called an active modified atmosphere when specific concentrations of gases are added around the fruits and inside a sealed package can provides a prior condition of balance and help to save lots of appropriate atmosphere for a extended period, this adds to the expansion of the time period of fruits (Jouki and Khazaei 2012).

Antioxidants factors prevent browning by decrease enzymatically shaped oquinones to colorless diphenols and shaping more stable colorless compounds

The profitable impact of ascorbic acid is due to several sides, for example, oxygen capture and protection, and the formation of a barrier that control the spread of oxygen towards the fruits so, productivity decreases of auxinones. Ascorbic acid is used for dip because it is harmless as well as being a necessary supplement for people, and its absence leads to clinical scurvy syndrome (Son et al 2001).

Likewise citric acid might is used as a chelating factor and an antioxidant, that works synergistically with L- ascorbic acid or different acids and their neutral salts to chelate peroxidants, which can cause inactivate enzymes. Both antioxidants (ascorbic and citric acid) as well as anti-stress factors, act as defense mechanisms and signaling molecules in some physiological processes of the plant (ElKobisy et al 2005) However, ascorbic acid has a positive role in cell division in addition to it acts as a cofactor action for many enzymes because of its function as an aid in biosynthesis of phytohormones for instance, gibberellin, abscisic acid and ethylene, ascorbic acid plays an essential regulatory role in many different physiological and biological cycles of plants. (Afsaneh et al 2018) .Citric acid has a necessary role in some signal transduction systems as it stabilizes membrane and function, activates metabolic enzymes, and transfers carbohydrates. Additionally, ascorbic acid and citric acid have auxinic activities that have stimulating results on the growth and productivity of most fruit trees.

(Ragab 2002). Besides, the antioxidants are considered as safe natural compounds for humans and animals. So, natural component and antioxidants are more satisfying quickly than synthetic ones (Asghari and Rashid 2015).

Salicylic acid is classified among the phenolic compounds which is broadly disseminated among plants and has a relationship with plant growth and development and the extent of disease resistance (Adel and Awad 2012). Positive effects of postharvest, to salicylic acid (SA) because in concise may be a phytohormone restraining ethylene biosynthesis and deferring the senescence (Bal and Celik 2010). Salicylic acid appears to inhibit the conversion of ACC to ethylene by inhibiting ACC oxidase action (Leslie and Romani 1988). SA is likewise related to neighborhood and foundational protection from microorganisms (Kang et al 2013). Additionally, dietary SA from vegetables and fruit are portrayed as bioactive compounds with medical aid potential (Hooper and Cassidy 2006), and thought of as commonly perceived as safe. There are several studies showing beneficial impacts of SA treatment on storability of fruits. Using salicylic acid as preharvest or postharvest applications reduces fruit rot in fruits by encouraging the guard resistance system and stimulation of antioxidant enzymes ( $\mathrm{Xu}$ and Tian 2008). However, SA fundamentally expanded protection from chilling injury in fruits for instance, peach (Wang et al 2006) and apricots (Satraj et al 2013). Preventing the increase in chilling-induced symptoms in the cell membranes. (Cao et al 2009). SA application during cold storage, inhibited ethylene production, reduced weight loss percentage, decay incidence, expanded marketable fruit percentage and maintained fruit firmness (Adel and Awad 2012).

Polyethylene glycol or PEGs may be a group of neutral, osmotic active polymers with high relative molecular mass, which is an inert, non-penetrating osmotic. PEG reduces to water potential of nutrient solutions without toxicity to plants (Kulkarni et al 2007). Osmotic and ion homeostasis are important for plant to be drought or salt tolerance. Osmotic homeostasis is consummated by collecting of congruent osmolytes within the cytosol (Al-Taha 2013). These incorporate free endogenous proline accumulation that participates in preventing stress-induced cellular damage by equation the cytoplasm osmotic potential with the surrounding environment (Santos-Diaz and Ochoa-Alejo 1994). PEG applica- 


\section{Synergistic Effect of Some Post-harvest Treatments and Passive Modified Atmosphere Packaging Conditions on Cold Storability of "Canino "Apricot Fruits}

tion promoted the production of soluble protein components, increased a membrane fusion and enhanced antioxidant action enzyme (Neelma and Faheem 2009). Exposure to polyethylene glycol solutions was wont to effectively simulate drought stress with limited metabolic interactions for instance, that related to the utilization of low relative molecular mass osmolates that the plant can ingest (Meher et al 2018). Polyethylene glycol stimulates water stress in plant tissue culture cells similarly it does within the cells of intact plants. (Patade et al 2012) Treating plants with polyethylene glycol improves the chilling resistance of soybean seeds (Neelma and Faheem 2009), is likewise used as a coating that reduces ethane permeability in fruits peel (Hagenmaier 2005). In addition, polyethylene glycol may be a common utilized in agricultural field's. Generates osmotic stress that reduces the speed of photosynthesis, and any stress on the mechanism of plant impacts of photosynthesis at the cellular level which incorporates colors, photosynthetic systems, electron transport system, pathways minimize carbon dioxide and decrease photosynthesis (Landjeva et al 2008, Sen and Alikamanoglu 2013).

The goal of this study are to evaluate the effect of SA, PEG and antioxidants (Ascorbic acid and citric acid combined) under two passive modified atmosphere packaging (MAP) to extend storability and reduce chilling injury of Canino apricots during storage at $1 \pm 1 \stackrel{\circ}{\circ}$ for 21 days followed by 5 days at $18 \pm 2 \stackrel{\circ}{ } \mathrm{C}$ as a marketing condition simulation.

\section{Materials and methods}

The present investigation was conducted during two successive seasons of 2018 and 2019 seasons on apricot fruits cv. 'Canino' (Prunus armeniaca L.). The fruits were harvested from a commercial orchard in Nubaria district, Behira Governoment. The fruits were harvested early morning at early ripe stage (greenish-yellow skin color and firm flesh) during the 1st week of June in both seasons and directly transferred to the Horticultural Department, Faculty of Agriculture, Ain Shams University, Cairo. The fruits were uniform size and maturity and any fruits with mechanically injured and defected fruits were removed. Then washed in chlorinated water chlorex (0.05\% Sodium hypochlorite) at $100 \mathrm{ppm}$ for 2 min., air dried and sorted.

The fruits were weighed for recorded their the initial fresh weight then subjected to pre- storage treatments as dipping for 5 minutes as follows:

1. Control rinsed in distilled water
2. Salicylic acid at $0.5 \mathrm{mM}$

3. Salicylic acid at $1.0 \mathrm{mM}$

4. Combined solutions of ascorbic and citric acid (AA:CA\%) 1.0:0.5 at $150 \mathrm{ppm}$

5. Combined solutions of ascorbic and citric acid (AA: CA \%) 1.0:1.0 at $150 \mathrm{ppm}$

6. Polyethylene Glycol (PEG 6000) at $0.2 \%$

7. Polyethylene Glycol (PEG 6000) at $0.4 \%$

8. After finished from all treatments, fruits were packed in two different passive modified atmosphere packaging (MAP), with two different type films.

1. The first passive modified atmosphere packaging, the fruits were placed in traditional containers Polyethylene terephthalate (PET). PET containers $\left(20 \mathrm{~cm}^{*} 12 \mathrm{~cm}{ }^{*} 6 \mathrm{~cm}\right)$ containing an antimicrobial pad on the bottom.

2. The second passive modified atmosphere packaging, the fruits were sealed in MAP made from a $35 \mu \mathrm{m}$ polypropylene film (PPF) with permeability of $474 \mathrm{~mL} \mathrm{O}_{2}\left(\mathrm{~m}^{2} \text { day atm }\right)^{-1}$ and $1507 \mathrm{~mL}$ $\mathrm{CO}_{2}\left(\mathrm{~m}^{2} \text { day atm }\right)^{-1}$.

Each treatment for each type of passive modified atmosphere packaging included 45 fruits (three replicates, 15 fruit per each replicate). The fruits from each treatment and replicate were stored at $1 \pm 1^{\circ} \mathrm{C}$ with $90 \%-95 \%$ relative humidity $(\mathrm{RH})$ for a 21 days followed by 5 days at $18 \pm 2{ }^{\circ} \mathrm{C}$ with $85-90$ $\%$ R.H as a marketing conditions simulation. The experiment was arranged in a randomized complete blocks design. (7 treatments $\times 3$ replicate $\times 2$ type of passive MAP)

Initial sample was taken randomly at the beginning of cold storage duration (0 day). After that, samples were taken weekly (7 days) from each replicate for all treatments during the storage period. A part of sample for each replicate was held at $18 \pm 2^{\circ} \mathrm{C}$ for 5 days as a marketing condition.

The following parameters were evaluated

\subsection{Fruit physical properties}

\subsubsection{Discarded fruits \%}

The number of decayed fruits was periodically recorded and expressed as percentage from the total fruit number.

\subsubsection{Weight loss $\%$}

The initial weight of apricots was recorded and fruit weight loss was calculated by weighing just after treatments application and every seven days interval during cold storage durations at $1+1^{\circ} \mathrm{C}$ and at the end and subsequent storage at $20+2^{\circ} \mathrm{C}$ for 5 days. 


\subsubsection{Chilling injury scale I index}

Symptoms of chilling injury $(\mathrm{Cl})$ were visually assessed upon removal of the fruits from cold storage conditions. The degree of $\mathrm{Cl}$ severity, based on external damage, according to (Lafuente et al 2003), was recorded subjective scale $1=$ no damage (none), 2=trace, 3=slight, 4=moderate, 5=severe, The $\mathrm{Cl}$ index was calculated according to the following formula: $\mathrm{Cl}=\Sigma$ (value of hedonic scale) $\times$ (number of fruit with the corresponding scale number)/ total number of fruit in the sample. Fruit was considered unacceptable for the consumer if it had $\mathrm{Cl}$ indices of 3 or higher.

\subsubsection{Fruit firmness (Kgf)}

It was recorded by Tester (GY-1, China) appendixes with a 2-mm plunger tip a digital force gauge. The firmness values were calculated by kilo gram force (Kgf)

\subsection{Chemical constituents}

- Total Soluble solids \% was determined according to A.O.A.C. (2005).

- Total acidity (as g Malic acid/100 g fruit fresh weight) was determined according to A.O.A.C. (2005).

- L-ascorbic acid content (mg/100g fruit fresh weight) was determined following the methods by A.O.A.C. (2005).

- Total phenoles (as mg gallic acid/ $100 \mathrm{~g}$ fruit fresh weight): Were determined in fruit juice extract were determined by the colorimetric method of folin.- Denis as described by Daniel and George (1972).

- Total carotenoids content (mg/100 g fresh weight) : was decided, according to the method of Wellburn (1994) .

\subsection{Physiological attributes}

\subsubsection{Enzymes activities}

Peroxidase enzyme activity (as $\mu \mathrm{mol}$ min-1 mg1 protein.) was determined according to Herzog and Fahimi (1973), and Catalase enzyme activity (as $\mu \mathrm{mol}$ min-1 mg-1 protein.) was estimated by Clairbone (1985).

\subsubsection{Electrolyte leakage \% (EC leakage)}

Weighed $10 \mathrm{~g}$ disks of the fruits apricot tissues and added $30 \mathrm{ml}$ of deionized water and magnetically stirred for 15 minutes. The electrical conductivity (EC) of the catalytic solution was measured with electrical conductivity meter. The experiment was repeated again but with homogeneity of tissues in the mixer and EC level measurement. The percentage of solute leakage was calculated as the EC leak using the method described by Mirdehghan et al (2007).

\subsubsection{Respiration rate}

( $\mathrm{mg} \mathrm{CO}_{2} / \mathrm{kg}$ fresh fruits $/ \mathrm{hr}$ ): $\mathrm{CO}_{2}$ created by apricots was decided after ten hours concluded from treatments and then every 7 days during cold storage and marketing periods. The air-flow was passed through concentrated $\mathrm{NaOH}$, to secure, that air-flow is $\mathrm{CO}_{2}$ free, before passing into 1-liter jar container, $500 \mathrm{gm}$./jar was count each replicate. The out-coming air-flow was then thread into 100 $\mathrm{ml} \mathrm{NaOH}$ of $0.1 \mathrm{~N}$ for $1 \mathrm{~h}$. Such solution was then titrated against $0.1 \mathrm{~N} \mathrm{HCl}$ and $\mathrm{CO}_{2}$ levels created by the apricots fresh was measured as $\left(\mathrm{mg} \mathrm{CO}_{2} / \mathrm{kg}\right.$ fresh fruits /hr), according to A.O.A.C. (2005).

\section{Statistical analysis}

Data were analyzed for statistical significant differences using MSTAT-C software (MSTAT, Michigan University East Lansing). Duncan multiple rang test (LSR) at $5 \%$ level was completed to define any significant difference among various treatments, according to Steel et al (1997).

\section{Results and disscution}

\subsection{Physical properties}

\subsubsection{Discarded fruits \%}

It is clear from data in Table 1 that both modified atmosphere packaging and supplementary refrigeration treatments greatly affected discarded fruits \% of "Canino" fruit either at cold storage at $1 \pm 1^{\circ} \mathrm{C}$ or at marketing period at $18 \pm 2^{\circ} \mathrm{C}$.

After 21 days of cold storage, the least discarded fruits \% were obtained by $1 \mathrm{mM} \mathrm{SA}, 0.4 \mathrm{PEG}$ and the combined treatment of $1 \mathrm{mM}$ Ascorbic +0.5 $\mathrm{mM}$ Citric acid without significant differences between them, either with traditional containers named polyethylene terephthalate (PET) or polypropylene film (PPF) in both seasons. 


\section{Synergistic Effect of Some Post-harvest Treatments and Passive Modified Atmosphere Packaging Conditions on Cold Storability of "Canino "Apricot Fruits}

Table 1. Effect of some post-harvest substances dipping and type of passive modified atmosphere packaging on discarded fruits \% of "Canino" apricot fruits stored at $1 \pm 1^{\circ} \mathrm{C}$ followed by 5 days at $18 \pm 2{ }^{\circ} \mathrm{C}$ during 2018 and 2019 seasons

\begin{tabular}{|c|c|c|c|c|c|c|c|c|}
\hline \multirow{4}{*}{ Treatments } & \multicolumn{8}{|c|}{ Passive Modified Atmosphere Packaging } \\
\hline & \multicolumn{4}{|c|}{ Polyethylene terephthalate (PET) } & \multicolumn{4}{|c|}{ Polypropylene film (PPF) } \\
\hline & \multicolumn{3}{|c|}{$\begin{array}{l}\text { Days in cold storage } \\
\qquad\left(1 \pm 1^{\circ} \mathrm{C}\right)\end{array}$} & \multirow{2}{*}{$\begin{array}{c}5 \text { days } \\
\text { at } \\
18 \pm 2^{\circ} \mathrm{C}\end{array}$} & \multicolumn{3}{|c|}{$\begin{array}{l}\text { Days in cold storage } \\
\qquad\left(1 \pm 1^{\circ} \mathrm{C}\right)\end{array}$} & \multirow{2}{*}{$\begin{array}{c}5 \text { days } \\
\text { at } \\
18 \pm 2^{\circ} \mathrm{C}\end{array}$} \\
\hline & 7 & 14 & 21 & & 7 & 14 & 21 & \\
\hline \multicolumn{9}{|c|}{2018 Season } \\
\hline Control & 0.00 & $6.67 \mathrm{a}$ & $13.34 \mathrm{a}$ & $25.00 \mathrm{a}$ & 0.00 & $3.34 \mathrm{a}$ & $8.34 \mathrm{a}$ & $16.67 \mathrm{a}$ \\
\hline $0.5 \mathrm{mM} \mathrm{SA}$ & 0.00 & $3.34 \mathrm{bc}$ & $11.67 \mathrm{ab}$ & $18.33 \mathrm{bc}$ & 0.00 & $3.34 \mathrm{a}$ & $6.67 \mathrm{ab}$ & $11.67 \mathrm{~b}$ \\
\hline $1.0 \mathrm{mM} \mathrm{SA}$ & 0.00 & $1.67 \mathrm{c}$ & $3.34 \mathrm{~d}$ & $8.34 \mathrm{e}$ & 0.00 & $0.00 \mathrm{~b}$ & $0.00 \mathrm{c}$ & $3.34 \mathrm{~d}$ \\
\hline $1.0: 0.5 \mathrm{~A}: \mathrm{C}$ & 0.00 & $1.67 \mathrm{a}$ & $6.67 \mathrm{c}$ & $15.00 \mathrm{~cd}$ & 0.00 & $0.00 \mathrm{~b}$ & $1.67 \mathrm{bc}$ & $6.67 \mathrm{~cd}$ \\
\hline 1.0:1.0 A: C & 0.00 & $5.00 \mathrm{ab}$ & $11.67 \mathrm{ab}$ & $20.00 \mathrm{ab}$ & 0.00 & $1.67 \mathrm{ab}$ & $3.34 \mathrm{~b}$ & $13.34 \mathrm{ab}$ \\
\hline $0.2 \%$ PEG & 0.00 & $5.00 \mathrm{ab}$ & $10.00 \mathrm{~b}$ & $16.67 \mathrm{bc}$ & 0.00 & $0.00 \mathrm{~b}$ & $3.34 \mathrm{~b}$ & $10.00 \mathrm{bc}$ \\
\hline $0.4 \%$ PEG & 0.00 & $1.67 \mathrm{c}$ & $5.00 \mathrm{~cd}$ & $11.67 \mathrm{de}$ & 0.00 & $0.00 \mathrm{~b}$ & $0.00 \mathrm{c}$ & $5.00 \mathrm{~d}$ \\
\hline \multicolumn{9}{|c|}{2019 Season } \\
\hline Control & 0.00 & $8.34 \mathrm{a}$ & $16.67 \mathrm{a}$ & $28.34 \mathrm{a}$ & 0.00 & $3.34 \mathrm{a}$ & $6.67 \mathrm{a}$ & $15.00 \mathrm{a}$ \\
\hline $0.5 \mathrm{mM}$ SA & 0.00 & $5.00 \mathrm{ab}$ & $11.67 \mathrm{~b}$ & $20.00 \mathrm{~b}$ & 0.00 & $1.67 \mathrm{ab}$ & $6.67 \mathrm{a}$ & $13.34 \mathrm{ab}$ \\
\hline $1.0 \mathrm{mM} \mathrm{SA}$ & 0.00 & $0.00 \mathrm{c}$ & $1.67 \mathrm{~d}$ & $5.00 \mathrm{~d}$ & 0.00 & $0.00 \mathrm{~b}$ & $0.00 \mathrm{~d}$ & $0.00 \mathrm{~d}$ \\
\hline $1.0: 0.5 \mathrm{~A}: \mathrm{C}$ & 0.00 & $3.34 \mathrm{bc}$ & $5.00 \mathrm{~cd}$ & $11.67 \mathrm{c}$ & 0.00 & $0.00 \mathrm{~b}$ & $3.34 \mathrm{bc}$ & $8.34 \mathrm{c}$ \\
\hline 1.0:1.0 A: C & 0.00 & $6.67 \mathrm{ab}$ & $10.00 \mathrm{~b}$ & $18.33 \mathrm{~b}$ & 0.00 & $0.00 \mathrm{~b}$ & $5.00 \mathrm{ab}$ & $11.67 \mathrm{bc}$ \\
\hline $0.2 \%$ PEG & 0.00 & $3.34 \mathrm{bc}$ & $8.34 \mathrm{bc}$ & $15.00 \mathrm{bc}$ & 0.00 & $0.00 \mathrm{~b}$ & $1.67 \mathrm{~cd}$ & $8.34 \mathrm{c}$ \\
\hline $0.4 \%$ PEG & 0.00 & $1.67 \mathrm{c}$ & $3.34 \mathrm{~d}$ & $10.00 \mathrm{c}$ & 0.00 & 0.0 & $0.0 \mathrm{~d}$ & $3.34 \mathrm{~d}$ \\
\hline
\end{tabular}

Values followed by the same letter (s) are not significantly different at $5 \%$ level

However, the second type of passive modified atmosphere (PPF) was more effective than the first type of passive modified atmosphere (PET) in minimizing the discarded Canino fruits \%. Data recorded on discarded fruit \% during marketing period at $18 \pm$ $2^{\circ} \mathrm{C}$ for 5 days showed that, all applied treatments were effective than control in this respect, and the three treatments which previously mentioned were also effective in reducing discarded fruits \% during marketing period.

\subsubsection{Chilling injury (Score).}

Data in Table (2) show the effect of some pre storage treatments in combination with two types of modified atmosphere packaging on chilling injury incidence of "Canino" apricot fruits either at cold storage or at marketing simulation conditions.
Generally, it could be noticed that all used treatments were effective than control in reducing chilling injury score but the treatments of $1 \mathrm{mM} \mathrm{SA}$ and $0.4 \%$ PEG were more effective than other treatments in this regard. However, the second type of passive modified atmosphere (PPF) was effective in reducing the incidence of chilling injury symptoms. During marketing period for 5 days at $18 \pm 2^{\circ} \mathrm{C}$. All applied treatments greatly decreased the incidence of chilling injury than control with the two types of passive MAP. However, second type of passive MAP was more effective than the first type of passive MAP regardless of the used treatments. Also, it could noticed that, chilling injury symptoms was, in general, recorded less values in Canino apricot fruits regardless of the used treatments or MAP type due to apricot fruits are deciduous fruits and did not suffer from storage at $1 \pm 1^{\circ} \mathrm{C}$ for short period (21 days) as found in this work. 
Table 2. Effect of some post-harvest substances dipping and type of passive modified atmosphere packaging on chilling injury (score) of Canino apricot fruits stored at $1 \pm 1^{\circ} \mathrm{C}$ followed by 5 days at $18 \pm 2^{\circ} \mathrm{C}$ during 2018 and 2019 seasons

\begin{tabular}{|c|c|c|c|c|c|c|c|c|}
\hline \multirow{4}{*}{ Treatments } & \multicolumn{8}{|c|}{ Passive Modified Atmosphere Packaging } \\
\hline & \multicolumn{4}{|c|}{ Polyethylene Terephthalate (PET) } & \multicolumn{4}{|c|}{ Polypropylene Film (PPF) } \\
\hline & \multicolumn{3}{|c|}{$\begin{array}{c}\text { Days in cold storage } \\
\left(1 \pm 1^{\circ} \mathrm{C}\right)\end{array}$} & \multirow{2}{*}{$\begin{array}{c}5 \text { days } \\
\text { at } \\
18 \pm 2^{\circ} \mathrm{C}\end{array}$} & \multicolumn{3}{|c|}{$\begin{array}{c}\text { Days in cold storage } \\
\left(1 \pm 1^{\circ} \mathrm{C}\right)\end{array}$} & \multirow{2}{*}{$\begin{array}{c}5 \text { days } \\
\text { at } \\
18 \pm 2^{\circ} \mathrm{C}\end{array}$} \\
\hline & 7 & 14 & 21 & & 7 & 14 & 21 & \\
\hline \multicolumn{9}{|c|}{2018 Season } \\
\hline Control & 1.00 & $1.42 \mathrm{a}$ & $1.83 \mathrm{a}$ & $2.75 \mathrm{a}$ & 1.00 & $1.25 \mathrm{a}$ & $1.56 \mathrm{a}$ & $1.92 \mathrm{a}$ \\
\hline $0.5 \mathrm{mM} \mathrm{SA}$ & 1.00 & $1.30 \mathrm{ab}$ & $1.70 \mathrm{ab}$ & $2.40 a b$ & 1.00 & $1.10 \mathrm{ab}$ & $1.40 \mathrm{ab}$ & $1.67 \mathrm{ab}$ \\
\hline $1.0 \mathrm{mM} \mathrm{SA}$ & 1.00 & $1.10 \mathrm{~b}$ & $1.25 \mathrm{c}$ & $1.58 \mathrm{~d}$ & 1.00 & $1.00 \mathrm{~b}$ & $1.00 \mathrm{~d}$ & $1.17 \mathrm{c}$ \\
\hline $1.0: 0.5 \mathrm{~A}: \mathrm{C}$ & 1.00 & $1.20 \mathrm{~b}$ & $1.50 \mathrm{bc}$ & $1.89 \mathrm{~cd}$ & 1.00 & $1.00 \mathrm{~b}$ & $1.13 \mathrm{~cd}$ & $1.40 \mathrm{bc}$ \\
\hline 1.0:1.0 A: C & 1.00 & $1.36 \mathrm{ab}$ & $1.75 \mathrm{ab}$ & $2.20 \mathrm{bc}$ & 1.00 & $1.13 \mathrm{ab}$ & $1.32 \mathrm{bc}$ & $1.58 \mathrm{~b}$ \\
\hline $0.2 \%$ PEG & 1.00 & $1.25 \mathrm{ab}$ & $1.66 \mathrm{ab}$ & $2.08 \mathrm{bc}$ & 1.00 & $1.00 \mathrm{~b}$ & $1.25 \mathrm{bc}$ & $1.46 \mathrm{bc}$ \\
\hline $0.4 \%$ PEG & 1.00 & $1.10 \mathrm{~b}$ & $1.36 \mathrm{c}$ & $1.80 \mathrm{~cd}$ & 1.00 & $1.00 \mathrm{~b}$ & $1.00 \mathrm{~d}$ & $1.25 \mathrm{c}$ \\
\hline \multicolumn{9}{|c|}{2019 Season } \\
\hline Control & 1.00 & $1.74 \mathrm{a}$ & $2.36 \mathrm{a}$ & $3.12 \mathrm{a}$ & 1.00 & $1.42 \mathrm{a}$ & $1.75 \mathrm{a}$ & $2.34 \mathrm{a}$ \\
\hline $0.5 \mathrm{mM} \mathrm{SA}$ & 1.00 & $1.49 \mathrm{bc}$ & $1.97 \mathrm{~b}$ & $2.56 \mathrm{~b}$ & 1.00 & $1.30 \mathrm{ab}$ & $1.53 \mathrm{bc}$ & $1.96 \mathrm{bc}$ \\
\hline $1.0 \mathrm{mM} \mathrm{SA}$ & 1.00 & $1.24 \mathrm{~d}$ & $1.49 \mathrm{~d}$ & $1.78 \mathrm{~d}$ & 1.00 & $1.00 \mathrm{c}$ & $1.16 \mathrm{~d}$ & $1.48 \mathrm{~d}$ \\
\hline $1.0: 0.5 \mathrm{~A}: \mathrm{C}$ & 1.00 & $1.34 \mathrm{~cd}$ & $1.72 \mathrm{c}$ & $1.94 \mathrm{~cd}$ & 1.00 & $1.13 \mathrm{bc}$ & $1.34 \mathrm{~cd}$ & $1.74 \mathrm{c}$ \\
\hline 1.0:1.0 A:C & 1.00 & $1.51 \mathrm{bc}$ & $1.84 \mathrm{bc}$ & $2.27 \mathrm{bc}$ & 1.00 & $1.21 \mathrm{~b}$ & $1.62 \mathrm{ab}$ & $2.03 \mathrm{~b}$ \\
\hline $0.2 \%$ PEG & 1.00 & $1.57 \mathrm{ab}$ & $1.79 \mathrm{bc}$ & $2.10 \mathrm{~cd}$ & 1.00 & $1.13 \mathrm{bc}$ & $1.41 \mathrm{c}$ & $1.88 \mathrm{bc}$ \\
\hline $0.4 \%$ PEG & 1.00 & $1.38 \mathrm{~b}-\mathrm{d}$ & $1.54 \mathrm{~d}$ & $1.85 \mathrm{~d}$ & 1.00 & $1.00 \mathrm{c}$ & $1.21 \mathrm{~d}$ & $1.53 \mathrm{~d}$ \\
\hline
\end{tabular}

Values followed by the same letter (s) are not significantly different at $5 \%$ level

\subsubsection{Weight loss \%}

Table 3 data showed that weight less \% of "Canino" apricot fruits was increased with advanced in cold storage durations followed by 5 days at 18 $\pm 2^{\circ} \mathrm{C}$ regardless of the used treatments or passive modified atmosphere type. However, all applied treatments were effective in reducing weight loss $\%$ than control either during cold storage at $1 \pm 1^{\circ} \mathrm{C}$ for 21 days or followed by 5 days as a marketing period simulation. Additionally, the treatments of 1 $\mathrm{mM} \mathrm{SA}$ and $0.4 \%$ PEG were effective than other treatments in recording less values of weight loss $\%$ either during cold storage at $1 \pm 1^{\circ} \mathrm{C}$ for 21 days followed by 5 days at $18 \pm 2^{\circ} \mathrm{C}$ as simulation at marketing period. The second type of passive MAP (polypropylene film, PPF) was more effective than first type of passive MAP (Polyethylene terephthalate, PET) in this respect during all cold storage durations and marketing period. For instance weight loss \% reached to $7.16 \& 3.66 \%$ in control against $3.45 \& 1.77 \%$ for $1 \mathrm{mM} \mathrm{SA}$ treatments with the both types of passive modified atmosphere during the first season.

\subsubsection{Fruit firmness (Kgf.)}

Table 4 showed that, both studied factors greatly affected "Canino" apricot fruit firmness during cold storage at $1 \pm 1^{\circ} \mathrm{C}$ for 21 days followed by 5 days at $18 \pm 2^{\circ} \mathrm{C}$ as a marketing period simulation. Generally, all applied treatments were effective in minimizing the loss in fruit firmness than control during cold storage and marketing period's. The great effect in this respect was recorded by $1 \mathrm{mM} \mathrm{SA}$ and $0.4 \%$ PEG treatments than other treatments. However, the passive modified atmosphere type of polypropylene film (PPF) was effective in reserving the firmness of Canino fruits from losses during cold storage and marketing than the passive modified atmosphere type of Polyethylene terephthalate (PET). From these data, treated fruits with $1 \mathrm{mM}$ SA plus the second type of passive modified atmosphere (polypropylene film, PPF) recorded the highest values of firmness which reached $(3.84$ and $3.90 \mathrm{Kg} /$ force) at cold storage and (2.56 and $2,66 \mathrm{Kg} /$ force) at $18 \pm 2^{\circ} \mathrm{C}$ in both seasons. In contrast untreated fruits packed of Polyethylene terephthalate (PET) exhibited a sharp decrease in fruit firmness values which recorded ( 2.48 and $1.04 \mathrm{Kg}$ force) at first season and $(2.26$ and $0.98 \mathrm{Kg} /$ force) at the second season in the end period of the two storages respectively. 


\section{Synergistic Effect of Some Post-harvest Treatments and Passive Modified Atmosphere Packaging Conditions on Cold Storability of "Canino "Apricot Fruits}

Table 3. Effect of some post-harvest substances dipping and type of passive modified atmosphere packaging on weight loss \% of "Canino" apricot fruits stored at $1 \pm 1^{\circ} \mathrm{C}$ followed by 5 days at $18^{\circ} \mathrm{C}$ during 2018 and 2019 seasons

\begin{tabular}{|c|c|c|c|c|c|c|c|c|}
\hline \multirow{4}{*}{ Treatments } & \multicolumn{8}{|c|}{ Passive Modified Atmosphere Packaging } \\
\hline & \multicolumn{4}{|c|}{ Polyethylene Terephthalate (PET) } & \multicolumn{4}{|c|}{ Polypropylene Film (PPF) } \\
\hline & \multicolumn{3}{|c|}{$\begin{array}{l}\text { Days in cold storage } \\
\qquad\left(1 \pm 1^{\circ} \mathrm{C}\right)\end{array}$} & \multirow{2}{*}{$\begin{array}{c}5 \text { days } \\
\text { at } \\
18 \pm 2^{\circ} \mathrm{C}\end{array}$} & \multicolumn{3}{|c|}{$\begin{array}{l}\text { Days in cold storage } \\
\qquad\left(1 \pm 1^{\circ} \mathrm{C}\right)\end{array}$} & \multirow{2}{*}{$\begin{array}{c}5 \text { days } \\
\text { at } \\
18 \pm 2^{\circ} \mathrm{C}\end{array}$} \\
\hline & 7 & 14 & 21 & & 7 & 14 & 21 & \\
\hline \multicolumn{9}{|c|}{2018 Season } \\
\hline Control & $1.38 \mathrm{a}$ & $3.09 \mathrm{a}$ & $4.49 \mathrm{a}$ & $7.16 \mathrm{a}$ & $0.89 \mathrm{a}$ & $1.64 \mathrm{a}$ & $2.29 \mathrm{a}$ & $3.66 \mathrm{a}$ \\
\hline $0.5 \mathrm{mM} \mathrm{SA}$ & $1.35 \mathrm{a}$ & $2.61 \mathrm{bc}$ & $3.52 \mathrm{bc}$ & $6.29 \mathrm{a}$ & $0.86 \mathrm{a}$ & $1.42 \mathrm{~b}$ & $1.95 \mathrm{~b}$ & $3.12 \mathrm{~b}$ \\
\hline $1.0 \mathrm{mM} \mathrm{SA}$ & $0.97 c$ & $1.49 \mathrm{~d}$ & $2.17 \mathrm{e}$ & $3.45 \mathrm{~d}$ & $0.64 \mathrm{c}$ & $0.94 \mathrm{~cd}$ & $1.23 \mathrm{~d}$ & $1.77 \mathrm{e}$ \\
\hline 1.0:0.5 A :C & $1.14 \mathrm{bc}$ & $1.79 \mathrm{~d}$ & $\mathrm{~d}$ & $3 c$ & $0.71 \mathrm{bc}$ & $1.12 \mathrm{~cd}$ & $1.47 \mathrm{~cd}$ & $2.31 \mathrm{~d}$ \\
\hline 1.0:1.0 A: C & $1.21 \mathrm{ab}$ & $2.73 a b$ & $3.80 \mathrm{~b}$ & $5.16 \mathrm{~b}$ & $0.82 \mathrm{ab}$ & $1.27 \mathrm{bc}$ & $1.78 \mathrm{bc}$ & $2.65 c$ \\
\hline $0.2 \%$ PEG & $1.26 \mathrm{ab}$ & $2.31 \mathrm{c}$ & $3.16 \mathrm{~cd}$ & $5.44 \mathrm{~b}$ & $0.80 \mathrm{ab}$ & $1.38 \mathrm{~b}$ & $1.85 \mathrm{~b}$ & $2.93 \mathrm{bc}$ \\
\hline $0.4 \%$ PEG & $1.08 \mathrm{bc}$ & $1.53 \mathrm{~d}$ & $2.11 \mathrm{e}$ & $3.86 \mathrm{~cd}$ & $0.74 \mathrm{bc}$ & $0.97 \mathrm{bc}$ & $1.36 \mathrm{~d}$ & $2.18 d$ \\
\hline \multicolumn{9}{|c|}{2019 Season } \\
\hline Control & $1.46 \mathrm{a}$ & $2.57 \mathrm{a}$ & $4.11 \mathrm{a}$ & $6.84 \mathrm{a}$ & $0.94 \mathrm{a}$ & $1.73 \mathrm{a}$ & $2.42 \mathrm{a}$ & $3.87 \mathrm{a}$ \\
\hline $0.5 \mathrm{mM} \mathrm{SA}$ & $1.34 \mathrm{ab}$ & $2.14 \mathrm{~b}$ & $3.53 \mathrm{~b}$ & $6.23 \mathrm{a}$ & $0.88 \mathrm{ab}$ & $1.56 \mathrm{ab}$ & $2.11 \mathrm{ab}$ & $3.28 \mathrm{~b}$ \\
\hline $1.0 \mathrm{mM} \mathrm{SA}$ & $1.13 \mathrm{c}$ & $1.58 \mathrm{~cd}$ & $2.06 \mathrm{~d}$ & $3.24 \mathrm{~d}$ & $0.73 \mathrm{c}$ & $0.93 \mathrm{~d}$ & $1.17 \mathrm{~d}$ & $1.82 \mathrm{e}$ \\
\hline $1.0: 0.5 \mathrm{~A}: \mathrm{C}$ & $1.22 \mathrm{bc}$ & $1.87 \mathrm{bc}$ & $2.75 c$ & $4.37 \mathrm{c}$ & $0.80 \mathrm{bc}$ & $1.08 \mathrm{~cd}$ & $1.55 \mathrm{c}$ & $2.33 \mathrm{de}$ \\
\hline 1.0:1.0 A: C & $1.40 \mathrm{ab}$ & $2.11 \mathrm{~b}$ & $3.38 \mathrm{~b}$ & $5.18 b$ & $0.91 \mathrm{a}$ & $1.39 \mathrm{~b}$ & $1.94 \mathrm{~b}$ & $3.11 \mathrm{bc}$ \\
\hline $0.2 \%$ PEG & $1.31 \mathrm{a}-\mathrm{c}$ & $1.93 \mathrm{bc}$ & $3.12 \mathrm{bc}$ & $4.81 \mathrm{bc}$ & $0.85 \mathrm{ab}$ & $1.31 \mathrm{bc}$ & $1.75 \mathrm{bc}$ & $2.71 \mathrm{~cd}$ \\
\hline $0.4 \%$ PEG & $1.21 \mathrm{bc}$ & $1.49 \mathrm{~d}$ & $2.18 d$ & $3.62 \mathrm{~d}$ & $0.78 \mathrm{c}$ & $0.91 \mathrm{~d}$ & $1.24 \mathrm{~d}$ & $1.96 \mathrm{e}$ \\
\hline
\end{tabular}

Values followed by the same letter (s) are not significantly different at $5 \%$ level

Table 4. Effect of some post-harvest substances dipping and type of passive modified atmosphere packaging on fruit firmness (Kgf) of "Canino" apricot fruits stored at $1 \pm 1^{\circ} \mathrm{C}$ followed by 5 days at $18 \pm 2^{\circ} \mathrm{C}$ during 2018 and 2019 seasons.

\begin{tabular}{|c|c|c|c|c|c|c|c|c|}
\hline \multirow{4}{*}{ Treatments } & \multicolumn{8}{|c|}{ Passive Modified Atmosphere Packaging } \\
\hline & \multicolumn{4}{|c|}{ Polyethylene Terephthalate (PET) } & \multicolumn{4}{|c|}{ Polypropylene Film (PPF) } \\
\hline & \multicolumn{3}{|c|}{$\begin{array}{l}\text { Days in cold storage } \\
\qquad\left(1 \pm 1^{\circ} \mathrm{C}\right)\end{array}$} & \multirow{2}{*}{$\begin{array}{c}5 \text { days } \\
\text { at } \\
18 \pm 2^{\circ} \mathrm{C}\end{array}$} & \multicolumn{3}{|c|}{$\begin{array}{l}\text { Days in cold storage } \\
\qquad\left(1 \pm 1^{\circ} \mathrm{C}\right)\end{array}$} & \multirow{2}{*}{$\begin{array}{c}5 \text { days } \\
\text { at } \\
18 \pm 2^{\circ} \mathrm{C}\end{array}$} \\
\hline & 7 & 14 & 21 & & 7 & 14 & 21 & \\
\hline \multicolumn{9}{|c|}{2018 Season } \\
\hline Control & $5.10 \mathrm{c}$ & $3.76 \mathrm{~d}$ & $2.48 \mathrm{~d}$ & $1.04 \mathrm{e}$ & $5.38 \mathrm{~b}$ & $3.96 \mathrm{~d}$ & $2.72 \mathrm{e}$ & $1.42 \mathrm{e}$ \\
\hline $0.5 \mathrm{mM} \mathrm{SA}^{1}$ & $4.92 \mathrm{c}$ & $3.98 \mathrm{~cd}$ & $2.64 \mathrm{~d}$ & $1.36 \mathrm{~d}$ & $5.42 \mathrm{~b}$ & $4.14 \mathrm{~cd}$ & $3.12 \mathrm{~d}$ & $1.66 \mathrm{~d}$ \\
\hline $1.0 \mathrm{mM} \mathrm{SA}$ & $5.44 \mathrm{ab}$ & $4.66 \mathrm{a}$ & $3.68 \mathrm{a}$ & $2.14 \mathrm{a}$ & $5.84 \mathrm{a}$ & $4.78 \mathrm{a}$ & $3.84 \mathrm{a}$ & $2.56 \mathrm{a}$ \\
\hline $1.0: 0.5 \mathrm{~A}: \mathrm{C}^{2}$ & $5.18 \mathrm{bc}$ & $4.32 \mathrm{~b}$ & $3.20 \mathrm{~b}$ & $1.76 \mathrm{~b}$ & $5.76 \mathrm{a}$ & $4.56 \mathrm{ab}$ & $3.40 \mathrm{~b}$ & $2.14 \mathrm{~b}$ \\
\hline 1.0:1.0 A: C & $5.00 \mathrm{c}$ & $4.16 \mathrm{bc}$ & $2.90 \mathrm{c}$ & $1.54 \mathrm{~cd}$ & $5.58 \mathrm{ab}$ & $4.33 \mathrm{bc}$ & $3.14 \mathrm{~cd}$ & $1.82 \mathrm{~cd}$ \\
\hline $0.2 \% \mathrm{PEG}^{3}$ & $5.28 \mathrm{ab}$ & $4.12 \mathrm{bc}$ & $3.04 \mathrm{bc}$ & $1.70 \mathrm{bc}$ & $5.64 \mathrm{ab}$ & $4.48 \mathrm{ab}$ & $3.32 \mathrm{bc}$ & $1.94 \mathrm{c}$ \\
\hline $0.4 \%$ PEG & $5.52 \mathrm{a}$ & $4.74 \mathrm{a}$ & $3.82 \mathrm{a}$ & $2.06 \mathrm{a}$ & $5.72 \mathrm{a}$ & $4.64 \mathrm{a}$ & $3.47 \mathrm{~b}$ & $2.30 \mathrm{~b}$ \\
\hline \multicolumn{9}{|c|}{2019 Season } \\
\hline Control & $4.44 \mathrm{c}$ & $3.60 \mathrm{~d}$ & $2.26 \mathrm{~d}$ & $0.98 \mathrm{e}$ & $4.90 \mathrm{c}$ & $4.00 \mathrm{~d}$ & $2.78 \mathrm{~d}$ & $1.34 \mathrm{e}$ \\
\hline $0.5 \mathrm{mM} \mathrm{SA}$ & $4.66 \mathrm{bc}$ & $3.78 \mathrm{~cd}$ & $2.42 \mathrm{~d}$ & $1.27 \mathrm{~d}$ & $5.02 \mathrm{c}$ & $4.27 \mathrm{~cd}$ & $3.08 \mathrm{c}$ & $1.60 \mathrm{~d}$ \\
\hline $1.0 \mathrm{mM} \mathrm{SA}$ & $5.08 \mathrm{a}$ & $4.26 \mathrm{ab}$ & $3.58 \mathrm{ab}$ & $2.29 \mathrm{a}$ & $5.36 \mathrm{a}$ & $4.75 \mathrm{a}$ & $3.90 \mathrm{a}$ & $2.66 \mathrm{a}$ \\
\hline $1.0: 0.5 \mathrm{~A}: \mathrm{C}$ & $4.64 \mathrm{bc}$ & $4.04 \mathrm{bc}$ & $3.36 \mathrm{~b}$ & $1.89 \mathrm{~b}$ & $5.28 \mathrm{ab}$ & $4.52 \mathrm{ab}$ & $3.61 \mathrm{~b}$ & $2.08 \mathrm{c}$ \\
\hline 1.0:1.0 A: C & $4.86 \mathrm{ab}$ & $3.84 \mathrm{~cd}$ & $2.86 \mathrm{c}$ & $1.62 \mathrm{c}$ & $5.10 \mathrm{bc}$ & $4.33 \mathrm{bc}$ & $3.25 \mathrm{c}$ & $2.10 \mathrm{c}$ \\
\hline $0.2 \%$ PEG & $4.58 \mathrm{bc}$ & $3.92 \mathrm{c}$ & $2.94 \mathrm{c}$ & $1.76 \mathrm{bc}$ & $5.22 a b$ & $4.40 \mathrm{bc}$ & $3.50 \mathrm{~b}$ & $2.24 \mathrm{bc}$ \\
\hline $0.4 \%$ PEG & $5.12 \mathrm{a}$ & $4.38 \mathrm{a}$ & $3.70 \mathrm{a}$ & $2.12 \mathrm{a}$ & $5.30 a b$ & $4.62 \mathrm{ab}$ & $3.67 \mathrm{~b}$ & $2.36 \mathrm{~b}$ \\
\hline
\end{tabular}

Values followed by the same letter (s) are not significantly different at $5 \%$ level

Initial sample recorded 6.12 and 5.74 (Kgf) for 2018 and 2019 seasons 
The impact of SA on chilling injury $(\mathrm{Cl})$ presumably ascribed to all the more diminishing level of glutathione and ascorbate reduce $\mathrm{O}_{2}$ aggregation and $\mathrm{H}_{2} \mathrm{O}_{2}$ aggregation increase. Oxidative stress induced by pooling of receptive oxygen species (ROS) with a decrease in antioxidant systems were related by chilling injury advancement in fruit through storage and its vigour capacity to initiate antioxidant systems decreasing the firmness of fruits in cold storage because membranes damage. (Jesus and Yahia 2003). Fruit firmness increased with SA may be due to metabolism of lignification, polyphenols and the lowering in extractable juice during storage time (Cai et al 2006).

PEG has increased wide attention as a biomaterial due to the fact of its high effectiveness in resisting protein adsorption and accurate compatibility with cells. Also it inhibit bacterial growth, due to the similar properties of the bonding surfactant, which prevents the action of cell membranes attributed to the double hydrophilic-hydrophobic character (Sweeney et al 2018). The reduction in decay and disorders development can also be controlled due to modified atmosphere packaging interestingly delayed fruits senescence and inhibited microbial increase and controlled the exponential growth of microorganisms (Nielsen and Lenfven 2008). Also, Allende et al (2007) located that $\mathrm{CO}_{2}$ inhibit microbial action due to it dissolves in water in the product and it has passive influence, on enzymic and biochemical activities in cells of each product and consequently microorganism. The positive part of shrink film as a result of reducing the physiological loss in weight of fruits (Singh and Rao 2005). Polymeric film packaging's have been used to maintain the high firmness of the pears (Mahajan et al 2013).

\subsection{Chemical constituents}

\subsubsection{Total Soluble Solids Content (TSS \%)}

Data in Table $\mathbf{5}$ show the effect of two types of passive modified atmosphere packaging and some pre storage treatments on TSS\% of "Canino" apricot fruits stored at $1 \pm 1^{\circ} \mathrm{C}$. After 7 days of cold storage, no significant differences were detected between different treatments, whereas after 21 days highest values of TSS\% were recorded by $0.4 \%$ PEG, 1.0 $\mathrm{mM}$ AS and combined treatment of ascorbic and citric acids (1:0.5) treatments without significant differences them .However during marketing period at $18 \pm 2^{\circ} \mathrm{C}$ for 5 days the highest TSS values were recorded by $1.0 \mathrm{mM}$ AS and $0.4 \%$ PEG without significant differences between them in both seasons and with both types of passive modified atmosphere packaging. However the second type of passive modified atmosphere packaging (polypropylene film, PPF) was more effective than the first type of MAP (Polyethylene Terephthalate, PET) in recording highest TSS values either at cold storage at $1 \pm 1^{\circ} \mathrm{C}$ for 21 days followed by 5 days at $18 \pm 2^{\circ} \mathrm{C}$ as a marketing period simulation. Generally, it could be mentioned that the increase of TSS\% with advanced in cold storage durations attributed to loss of water content and increasing of total soluble solids especially total sugars.

\subsubsection{Total acidity (g malic acid / $100 \mathrm{~g}$ fresh weight)}

Table 6 showed that total acidity content greatly affected with both studied factors in "Canino" apricot fruits during cold storage durations and marketing assimilation conditions. An evident decrease in fruit acidity of "Canino" apricot fruits were obtained with advanced in cold storage durations and during marketing period regardless of the used treatments or MAP type (polypropylene film, PPF). However, all applied treatments decreased fruit acidity than the control but the treatment of $1.0 \mathrm{mM} \mathrm{SA}$ was more effective in this respect than others. Regarding to the effect of passive MAP types, it is clear that the second type was more effect in pestering total acidity from losses during cold storage durations at $1 \pm 1^{\circ} \mathrm{C}$ or during marketing period at $18 \pm 2^{\circ} \mathrm{C}$ in both seasons. It could be concluded that the reduction of fruit acidity with advanced in cold storage durations followed by marketing period could be attributed to the consumption of these acids in fruit respiration through Krebs cycle pathway. 


\section{Synergistic Effect of Some Post-harvest Treatments and Passive Modified Atmosphere Packaging Conditions on Cold Storability of "Canino "Apricot Fruits}

Table 5. Effect of some post-harvest substances dipping and type of passive modified atmosphere packaging on total soluble solids content of "Canino" apricot fruits stored at $1 \pm 1^{\circ} \mathrm{C}$ followed by 5 days at $18 \pm 2^{\circ} \mathrm{C}$ during 2018 and 2019 seasons.

\begin{tabular}{|c|c|c|c|c|c|c|c|c|}
\hline \multirow{4}{*}{ Treatments } & \multicolumn{8}{|c|}{ Passive Modified Atmosphere Packaging } \\
\hline & \multicolumn{4}{|c|}{ Polyethylene Terephthalate (PET) } & \multicolumn{4}{|c|}{ Polypropylene Film (PPF) } \\
\hline & \multicolumn{3}{|c|}{$\begin{array}{l}\text { Days in cold storage } \\
\left(1 \pm 1^{\circ} \mathrm{C}\right)\end{array}$} & \multirow{2}{*}{$\begin{array}{c}5 \text { days } \\
\text { at } \\
18 \pm 2^{\circ} \mathrm{C}\end{array}$} & \multicolumn{3}{|c|}{$\begin{array}{l}\text { Days in cold storage } \\
\left(1 \pm 1^{\circ} \mathrm{C}\right)\end{array}$} & \multirow{2}{*}{$\begin{array}{l}5 \text { days } \\
\text { at } \\
18 \pm 2^{\circ} \mathrm{C}\end{array}$} \\
\hline & 7 & 14 & 21 & & 7 & 14 & 21 & \\
\hline \multicolumn{9}{|c|}{2018 Season } \\
\hline Control & $12.3 \mathrm{a}$ & $13.7 \mathrm{ab}$ & $12.4 \mathrm{~d}$ & $10.6 \mathrm{~d}$ & $12.7 \mathrm{a}$ & $13.8 \mathrm{a}$ & $13.1 \mathrm{~d}$ & $11.3 \mathrm{e}$ \\
\hline $0.5 \mathrm{mM} \mathrm{SA}$ & $12.6 \mathrm{a}$ & $13.3 \mathrm{~b}$ & $13.1 \mathrm{~d}$ & $12.0 \mathrm{c}$ & $12.5 \mathrm{a}$ & $13.3 \mathrm{~b}$ & $13.6 \mathrm{~cd}$ & $12.8 \mathrm{~d}$ \\
\hline $1.0 \mathrm{mM} \mathrm{SA}$ & $12.7 \mathrm{a}$ & $13.8 \mathrm{ab}$ & $14.7 \mathrm{ab}$ & $16.3 \mathrm{a}$ & $12.3 \mathrm{a}$ & $13.9 \mathrm{a}$ & $14.5 \mathrm{a}$ & $15.5 \mathrm{a}$ \\
\hline $1.0: 0.5 \mathrm{~A}: \mathrm{C}$ & $12.4 \mathrm{a}$ & $13.6 \mathrm{ab}$ & $14.6 \mathrm{ab}$ & $15.4 \mathrm{ab}$ & $12.3 \mathrm{a}$ & $13.5 \mathrm{ab}$ & $14.3 \mathrm{ab}$ & $14.8 \mathrm{ab}$ \\
\hline 1.0:1.0 A: C & $12.4 \mathrm{a}$ & $13.5 \mathrm{ab}$ & $13.8 \mathrm{c}$ & $13.1 \mathrm{c}$ & $12.6 \mathrm{a}$ & $13.2 \mathrm{~b}$ & $14.0 \mathrm{bc}$ & $13.7 \mathrm{c}$ \\
\hline $0.2 \%$ PEG & $12.5 \mathrm{a}$ & $13.6 \mathrm{ab}$ & $14.3 \mathrm{bc}$ & $14.6 \mathrm{~b}$ & $12.8 \mathrm{a}$ & $13.6 \mathrm{ab}$ & $14.2 \mathrm{ab}$ & $14.3 \mathrm{bc}$ \\
\hline $0.4 \%$ PEG & $12.8 \mathrm{a}$ & $14.0 \mathrm{a}$ & $15.0 \mathrm{a}$ & $15.9 \mathrm{a}$ & $12.5 \mathrm{a}$ & $13.8 \mathrm{a}$ & $14.7 \mathrm{a}$ & $15.3 \mathrm{a}$ \\
\hline \multicolumn{9}{|c|}{2019 Season } \\
\hline Control & $13.2 \mathrm{ab}$ & $14.7 \mathrm{a}$ & $13.2 \mathrm{~d}$ & $11.8 \mathrm{~d}$ & $13.4 \mathrm{a}$ & $14.1 \mathrm{ab}$ & $13.7 \mathrm{c}$ & $12.4 \mathrm{~d}$ \\
\hline $0.5 \mathrm{mM} \mathrm{SA}$ & $13.5 \mathrm{ab}$ & $14.1 \mathrm{bc}$ & $13.7 \mathrm{~d}$ & $\mathrm{c}$ & $13.4 \mathrm{a}$ & $13.6 \mathrm{~b}$ & $14.1 \mathrm{bc}$ & $13.6 \mathrm{c}$ \\
\hline $1.0 \mathrm{mM} \mathrm{SA}$ & $13.4 \mathrm{ab}$ & $14.5 \mathrm{ab}$ & $15.3 \mathrm{ab}$ & $16.7 \mathrm{a}$ & $13.3 \mathrm{a}$ & $14.3 \mathrm{a}$ & $15.1 \mathrm{a}$ & $15.9 \mathrm{a}$ \\
\hline $1.0: 0.5 \mathrm{~A}: \mathrm{C}$ & $13.1 \mathrm{~b}$ & $14.0 \mathrm{c}$ & $15.0 \mathrm{ab}$ & $15.6 \mathrm{~b}$ & $13.6 \mathrm{a}$ & $13.8 \mathrm{ab}$ & $14.6 \mathrm{ab}$ & $15.2 \mathrm{ab}$ \\
\hline $1.0: 1.0 \mathrm{~A}: \mathrm{C}$ & $13.6 \mathrm{a}$ & $14.6 \mathrm{ab}$ & $14.5 \mathrm{c}$ & $14.0 \mathrm{c}$ & $13.2 \mathrm{a}$ & $13.7 \mathrm{~b}$ & $14.2 \mathrm{~b}$ & $14.5 \mathrm{~b}$ \\
\hline $0.2 \%$ PEG & $13.7 \mathrm{a}$ & $14.3 \mathrm{bc}$ & $14.9 \mathrm{bc}$ & $15.2 \mathrm{~b}$ & $13.3 \mathrm{a}$ & $13.7 b$ & $14.4 \mathrm{~b}$ & $14.7 \mathrm{~b}$ \\
\hline $0.4 \%$ PEG & $13.7 \mathrm{a}$ & $14.8 \mathrm{a}$ & $15.5 \mathrm{a}$ & $16.2 \mathrm{ab}$ & $13.5 \mathrm{a}$ & $14.0 \mathrm{ab}$ & $14.9 \mathrm{a}$ & $15.6 \mathrm{a}$ \\
\hline
\end{tabular}

Values followed by the same letter (s) are not significantly different at $5 \%$ level Initial sample recorded 12.0 and $12.8 \%$ for 2018 and 2019 seasons

Table 6. Effect of some post-harvest substances dipping and type of passive modified atmosphere packaging on total acidity \% of "Canino" apricot fruits stored at $1 \pm 1^{\circ} \mathrm{C}$ followed by 5 days at $18 \pm 2^{\circ} \mathrm{C}$ during 2018 and 2019 seasons

\begin{tabular}{|c|c|c|c|c|c|c|c|c|}
\hline \multirow{4}{*}{ Treatments } & \multicolumn{8}{|c|}{ Passive Modified Atmosphere Packaging } \\
\hline & \multicolumn{4}{|c|}{ Polyethylene Terephthalate (PET) } & \multicolumn{4}{|c|}{ Polypropylene Film (PPF) } \\
\hline & \multicolumn{3}{|c|}{$\begin{array}{l}\text { Days in cold storage } \\
\qquad\left(1 \pm 1^{\circ} \mathrm{C}\right)\end{array}$} & \multirow{2}{*}{$\begin{array}{c}5 \text { days } \\
\text { at } \\
18 \pm 2^{\circ} \mathrm{C}\end{array}$} & \multicolumn{3}{|c|}{$\begin{array}{l}\text { Days in cold storage } \\
\left(1 \pm 1^{\circ} \mathrm{C}\right)\end{array}$} & \multirow{2}{*}{$\begin{array}{c}5 \text { days } \\
\text { at } \\
18 \pm 2^{\circ} \mathrm{C}\end{array}$} \\
\hline & 7 & 14 & 21 & & 7 & 14 & 21 & \\
\hline \multicolumn{9}{|c|}{2018 Season } \\
\hline Control & $1.42 \mathrm{a}$ & $1.23 \mathrm{ab}$ & $1.16 \mathrm{a}$ & $1.23 \mathrm{a}$ & $1.51 \mathrm{a}$ & $1.29 \mathrm{ab}$ & $1.18 \mathrm{a}$ & $1.18 \mathrm{a}$ \\
\hline $0.5 \mathrm{mM} \mathrm{SA}$ & $1.44 \mathrm{a}$ & $1.20 \mathrm{a}-\mathrm{c}$ & $1.11 \mathrm{ab}$ & $1.09 \mathrm{~b}$ & $1.46 \mathrm{a}$ & $1.31 \mathrm{ab}$ & $1.13 \mathrm{ab}$ & $1.05 \mathrm{~b}$ \\
\hline $1.0 \mathrm{mM} \mathrm{SA}$ & $1.40 \mathrm{a}$ & $1.17 \mathrm{bc}$ & $0.93 \mathrm{~d}$ & $0.76 \mathrm{e}$ & $1.43 \mathrm{a}$ & $1.23 \mathrm{c}$ & $1.00 \mathrm{c}$ & $0.81 \mathrm{~d}$ \\
\hline $1.0: 0.5 \mathrm{~A}: \mathrm{C}$ & $1.45 \mathrm{a}$ & $1.14 \mathrm{c}$ & $1.00 \mathrm{~cd}$ & $0.83 \mathrm{de}$ & $1.46 \mathrm{a}$ & $1.28 \mathrm{a}-\mathrm{c}$ & $1.07 \mathrm{~b}$ & $0.89 \mathrm{~cd}$ \\
\hline $1.0: 1.0 \mathrm{~A}: \mathrm{C}$ & $1.48 \mathrm{a}$ & $1.25 \mathrm{a}$ & $1.05 \mathrm{bc}$ & $0.97 \mathrm{c}$ & $1.50 \mathrm{a}$ & $1.33 \mathrm{a}$ & $1.13 \mathrm{ab}$ & $1.02 \mathrm{~b}$ \\
\hline $0.2 \%$ PEG & $1.46 \mathrm{a}$ & $1.22 \mathrm{ab}$ & $1.07 \mathrm{~b}$ & $0.91 \mathrm{~cd}$ & $1.42 \mathrm{a}$ & $1.30 \mathrm{ab}$ & $1.10 \mathrm{~b}$ & $0.97 \mathrm{bc}$ \\
\hline $0.4 \%$ PEG & $1.41 \mathrm{a}$ & $1.18 \mathrm{a}-\mathrm{c}$ & $0.98 \mathrm{~cd}$ & $0.85 \mathrm{de}$ & $1.40 \mathrm{a}$ & $1.26 \mathrm{bc}$ & $0.95 \mathrm{c}$ & $0.86 \mathrm{~d}$ \\
\hline \multicolumn{9}{|c|}{2019 Season } \\
\hline Control & $1.36 \mathrm{a}$ & $1.19 \mathrm{c}$ & $1.13 \mathrm{a}$ & $1.18 \mathrm{a}$ & $1.42 \mathrm{a}$ & $1.20 \mathrm{a}-\mathrm{c}$ & $1.16 \mathrm{a}$ & $1.21 \mathrm{a}$ \\
\hline $0.5 \mathrm{mM} \mathrm{SA}$ & $1.38 \mathrm{a}$ & $1.25 \mathrm{a}$ & $1.09 \mathrm{a}$ & $1.03 \mathrm{a}$ & $1.44 \mathrm{a}$ & $1.22 \mathrm{ab}$ & $1.08 \mathrm{~b}$ & $1.01 \mathrm{~b}$ \\
\hline $1.0 \mathrm{mM} \mathrm{SA}$ & $1.33 \mathrm{a}$ & $1.23 \mathrm{ab}$ & $0.91 \mathrm{~d}$ & $0.79 \mathrm{~d}$ & $1.37 \mathrm{a}$ & $1.17 \mathrm{bc}$ & $0.87 \mathrm{~d}$ & $0.80 \mathrm{~d}$ \\
\hline $1.0: 0.5 \mathrm{~A}: \mathrm{C}$ & $1.37 \mathrm{a}$ & $1.17 \mathrm{c}$ & $1.02 \mathrm{~b}$ & $0.81 \mathrm{~cd}$ & $1.40 \mathrm{a}$ & $1.25 \mathrm{a}$ & $1.00 \mathrm{c}$ & $0.86 \mathrm{~cd}$ \\
\hline 1.0:1.0 A: C & $1.33 \mathrm{a}$ & $1.24 \mathrm{a}$ & $1.03 \mathrm{~b}$ & $0.91 \mathrm{c}$ & $1.39 \mathrm{a}$ & $1.19 \mathrm{a}-\mathrm{c}$ & $1.05 \mathrm{bc}$ & $0.96 \mathrm{~b}$ \\
\hline $0.2 \%$ PEG & $1.36 \mathrm{a}$ & $1.20 \mathrm{a}-\mathrm{c}$ & $0.97 \mathrm{bc}$ & $0.85 \mathrm{~cd}$ & $1.43 \mathrm{a}$ & $1.23 \mathrm{ab}$ & $1.07 \mathrm{~b}$ & $0.93 \mathrm{bc}$ \\
\hline $0.4 \%$ PEG & $1.34 \mathrm{a}$ & $1.18 \mathrm{bc}$ & $0.93 \mathrm{~cd}$ & $0.76 \mathrm{~d}$ & $1.40 \mathrm{a}$ & $1.15 \mathrm{c}$ & $0.90 \mathrm{~d}$ & $0.87 \mathrm{~d}$ \\
\hline
\end{tabular}

Values followed by the same letter (s) are not significantly different at $5 \%$ level

Initial sample recorded 1.66 and $1.53 \%$ for 2018 and 2019 seasons 


\subsubsection{L-ascorbic acid (mg/100 $\mathrm{g}$ fresh weight)}

As it showed in Table 7, both studied factors greatly affected L-ascorbic acid content with of " $\mathrm{Ca}$ nino" apricot fruits during cold storage at $1 \pm 1^{\circ} \mathrm{C}$ for 21 days followed by 5 days at $18 \pm 2^{\circ} \mathrm{C}$. It is clear that $\mathrm{L}$-ascorbic acid content was reduced in cold storage period irrespective of the used treatments or passive MAP type. For example, L-ascorbic acid value was $16.67 \mathrm{mg} / 100 \mathrm{~g}$ fresh weight in the beginning of cold storage duration reduced to $10.56 \mathrm{mg} / 100 \mathrm{~g}$ fresh weight for control after 21 days of storage at $1 \pm 1^{\circ} \mathrm{C}$ in first season of study. However, all applied treatments were effective in reducing the rate of $\mathrm{L}$ ascorbic acid losses than control during cold storage durations or marketing period. After 21 days of cold storage and during marketing period, the highest values of $L-$ ascorbic acid were recorded by 1.0 Mm SA and $0.4 \%$ PEG in both seasons and both types of passive modified atmosphere packaging. The second type of passive modified atmosphere packaging (polypropylene film, PPF) was more effective than the first type (polyethylene terephthalate, PET) in presering L- ascorbic acid content from losses during cold storage at $1 \pm 1^{\circ} \mathrm{C}$ for 21 days followed by 5 days at $18 \pm 2^{\circ} \mathrm{C}$.

Alejandra et al (2017), illustrated that, the lowering patterns in total acidity during the duration of cold storage resulted from the decrease in the consumption of organic acids and their conversion into sugars during the metabolism process in the respiratory system and utilized by enzymatic activities. In addition, salicylic acid is efficiently protected the cell walls through lowering the degrading enzymes and end result prevented the rise in TSS content of the cells (Ezzat 2014). However, Lu et al (2011) found that salicylic acid belated the decline of ascorbic acid content and avoided its devastation, so enhance the fruit quality.

Application of citric acid on fruits has been proven to enhance catalase enzyme action (Yoruk et al 2005). It was also confirmed that treating plants with ascorbic acid and citric acid improved the quality of the fruit. For example, antioxidants, total soluble solids, total acidity, total sugars, ascorbic acid content, and crop yield improvement L-ascorbic acid content, and enhance crops yield (El-Hifny and El-Sayed 2011) and Khreba et al (2014) located that, packed film fruits safeguard its level of ascorbic acid contrast the control fruits during cold storage. The reduction in ascorbic acid values during the duration of cold storage may be due to the corrosion of ascorbic acid to dehydrocorbic acid, Furthermore, rise $\mathrm{CO}_{2}$ led to a delay the change in ascorbic acid level of fruits through cold storage (Akbudak 2008).
Packed strawberry fruits in passive modified atmosphere decreased respiration rate for this reason decreasing the lack of ascorbic acid (Mohammadi and Hanafi 2014).

\subsubsection{Total phenols $(\mathrm{mg} / 100 \mathrm{~g}$ f.wt.)}

It is clear from data in Table $\mathbf{8}$ that total phenols greatly affected with the post-harvest treatments and the two types of passive modified atmosphere packaging in "Canino" apricot fruits during cold storage and marketing durations. It is well known that, phenolic compounds are one of the defenses against chilling injury or low temperature effects during cold storage. The treated apricot fruits with 1.0 $\mathrm{mM} \mathrm{SA}, 0.4 \%$ PEG and combined treatment of Ascorbic and Citric acids (1:0.5) increased total phenols values during cold storage at $1 \pm 1^{\circ} \mathrm{C}$ for 21 days. On the contrary, the untreated apricot fruits or treated with low concentrations from the previous treatments led to a gradual decrease in the phenolic compounds Compared the initial sample. The treatments of $1.0 \mathrm{mM} \mathrm{SA}$ and $0.4 \%$ PEG were superior than other in this respect. Total phenol decreased from $0.483 \mathrm{mg} / 100 \mathrm{~g}$ f.wt as initial sample to 0.295 $\mathrm{mg} / 100 \mathrm{~g}$ f. wt.in control compared to an evident increase to $0.591 \mathrm{mg} / 100 \mathrm{~g}$ f.wt. in $1.0 \mathrm{mM} \mathrm{SA}$. The end of 5 days for marketing assimilation, total phenol was decreased either with treated or untreated fruits; the treatment of $1.0 \mathrm{mM} \mathrm{SA}$ was effective in recording the highest values of total phenols in both seasons and both types of passive modified atmosphere packaging. In addition, the second type of passive modified atmosphere packaging (polypropylene film, PPF) was more effective than the first type of passive MAP (polyethylene terephthalate, PET) in effecting total phenols of "Canino" apricot fruits. In general, Phenolic compounds act as natural antioxidants, inhibitors for the production of free radicals, and catalysts for the production of antioxidants are considered one of the most important secondary receptors necessary (Hossain et al 2009). The increase in the synthesis of phenols by ascorbic acid or citric acid is due to the positive role of antioxidants in lowering the respiratory rate. Ascorbic acid and citric acid have been shown to enhance the activity of the enzyme responsible for the biosynthesis of phenol in fruits. It also has an exogenous function and an important role in the accumulation of carbohydrates, thus forming soluble sugars and being basic substrates for the accumulation of various secondary receptors such as flavonoids and phenols, in excess by ascorbic and citric treatment (Shazly et al 2013). 


\section{Synergistic Effect of Some Post-harvest Treatments and Passive Modified Atmosphere Packaging Conditions on Cold Storability of "Canino "Apricot Fruits}

Table 7. Effect of some post-harvest substances dipping and type of passive modified atmosphere packaging on $\mathrm{L}$ Ascorbic acid (mg/100 g f.wt.) of "Canino" apricot fruits stored at $1 \pm 1^{\circ} \mathrm{C}$ followed by 5 days at $18^{\circ} \mathrm{C}$ during 2018 and 2019 seasons

\begin{tabular}{|c|c|c|c|c|c|c|c|c|}
\hline \multirow{4}{*}{ Treatments } & \multicolumn{8}{|c|}{ Passive Modified Atmosphere Packaging } \\
\hline & \multicolumn{4}{|c|}{ Polyethylene Terephthalate (PET) } & \multicolumn{4}{|c|}{ Polypropylene Film (PPF) } \\
\hline & \multicolumn{3}{|c|}{$\begin{array}{l}\text { Days in cold storage } \\
\left(1 \pm 1^{\circ} \mathrm{C}\right)\end{array}$} & \multirow{2}{*}{$\begin{array}{c}5 \text { days } \\
\text { at } \\
18 \pm 2^{\circ} \mathrm{C}\end{array}$} & \multicolumn{3}{|c|}{$\begin{array}{c}\text { Days in cold storage } \\
\left(1 \pm 1^{\circ} \mathrm{C}\right)\end{array}$} & \multirow{2}{*}{$\begin{array}{c}5 \text { days } \\
\text { at } \\
18 \pm 2^{\circ} \mathrm{C}\end{array}$} \\
\hline & 7 & 14 & 21 & & 7 & 14 & 21 & \\
\hline \multicolumn{9}{|c|}{2018 Season } \\
\hline Control & $14.72 \mathrm{~b}$ & $12.20 \mathrm{~d}$ & $10.56 \mathrm{~d}$ & $7.13 \mathrm{e}$ & $15.36 \mathrm{a}$ & $13.66 \mathrm{~d}$ & $11.84 \mathrm{e}$ & $8.41 \mathrm{e}$ \\
\hline $0.5 \mathrm{mM} \mathrm{SA}$ & $14.80 \mathrm{~b}$ & $12.74 \mathrm{~d}$ & $11.19 \mathrm{c}$ & $8.11 \mathrm{~d}$ & $15.51 \mathrm{a}$ & $14.41 \mathrm{~cd}$ & $5 d$ & $9.88 \mathrm{~d}$ \\
\hline $1.0 \mathrm{mM} \mathrm{SA}$ & $15.65 \mathrm{a}$ & $14.87 \mathrm{ab}$ & $13.75 \mathrm{a}$ & $11.72 \mathrm{a}$ & $16.17 \mathrm{a}$ & $16.01 \mathrm{a}$ & $5 \mathrm{a}$ & $13.16 \mathrm{a}$ \\
\hline $1.0: 0.5 \mathrm{~A}: \mathrm{C}$ & $15.44 \mathrm{ab}$ & $14.10 \mathrm{bc}$ & & $10.34 \mathrm{~b}$ & $15.78 \mathrm{a}$ & bc & $5 \mathrm{c}$ & $2 \mathrm{c}$ \\
\hline 1.0:1.0 A: C & $15.04 \mathrm{ab}$ & $13.42 \mathrm{c}$ & $11.78 \mathrm{c}$ & $9.03 \mathrm{c}$ & $15.54 \mathrm{a}$ & $14.63 \mathrm{bc}$ & $13.11 \mathrm{c}$ & $10.61 \mathrm{~cd}$ \\
\hline $0.2 \%$ PEG & $15.36 \mathrm{ab}$ & & $4 \mathrm{c}$ & & $15.72 \mathrm{a}$ & & & $10.25 d$ \\
\hline $0.4 \%$ PEG & $15.34 a b$ & $4 \mathrm{a}$ & $13.18 \mathrm{ab}$ & $11.16 \mathrm{a}$ & $16.13 \mathrm{a}$ & $a b$ & $9 \mathrm{~b}$ & $59 \mathrm{~b}$ \\
\hline \multicolumn{9}{|c|}{2019 Season } \\
\hline Control & $15.56 \mathrm{~b}$ & $13.56 \mathrm{c}$ & $11.55 \mathrm{~d}$ & $8.26 \mathrm{e}$ & $16.11 \mathrm{a}$ & $14.12 \mathrm{~d}$ & $12.06 \mathrm{~d}$ & $9.23 \mathrm{e}$ \\
\hline $0.5 \mathrm{mM} \mathrm{SA}$ & $15.62 \mathrm{~b}$ & $13.84 \mathrm{c}$ & $11.62 \mathrm{~d}$ & $9.53 \mathrm{~cd}$ & $16.14 \mathrm{a}$ & $14.36 \mathrm{~d}$ & $12.36 \mathrm{~cd}$ & $9.94 \mathrm{~d}$ \\
\hline $1.0 \mathrm{mM} \mathrm{SA}$ & $16.52 \mathrm{ab}$ & $14.75 \mathrm{ab}$ & $13.18 a b$ & $11.95 a b$ & $17.03 \mathrm{a}$ & $15.84 \mathrm{ab}$ & $14.67 \mathrm{a}$ & $13.58 \mathrm{a}$ \\
\hline $1.0: 0.5 \mathrm{~A}: \mathrm{C}$ & $16.05 \mathrm{ab}$ & $14.26 \mathrm{bc}$ & $12.91 \mathrm{~b}$ & $11.32 \mathrm{~b}$ & $16.36 \mathrm{a}$ & $15.23 \mathrm{bc}$ & $13.88 \mathrm{~b}$ & $12.07 \mathrm{~b}$ \\
\hline 1.0:1.0 A: C & $15.77 \mathrm{~b}$ & $13.87 \mathrm{c}$ & $12.16 \mathrm{~cd}$ & $9.34 \mathrm{~d}$ & $16.20 \mathrm{a}$ & $14.79 \mathrm{~cd}$ & $12.51 \mathrm{~cd}$ & $10.76 \mathrm{c}$ \\
\hline $0.2 \%$ PEG & $16.16 \mathrm{ab}$ & $14.05 \mathrm{bc}$ & $12.84 \mathrm{bc}$ & $10.16 \mathrm{c}$ & $16.25 \mathrm{a}$ & $14.59 \mathrm{~cd}$ & $12.95 \mathrm{c}$ & $11.21 \mathrm{c}$ \\
\hline $0.4 \%$ PEG & $16.81 \mathrm{a}$ & $15.10 \mathrm{a}$ & $13.74 \mathrm{a}$ & $12.13 a$ & $16.85 \mathrm{a}$ & $16.07 \mathrm{a}$ & $14.93 \mathrm{a}$ & 13.24 \\
\hline
\end{tabular}

Values followed by the same letter (s) are not significantly different at $5 \%$ level

Initial sample recorded 16.67 and 17.88 \& mg/100 g f.wt) for 2018 and 2019 seasons

Table 8. Effect of some post-harvest substances dipping and type of passive modified atmosphere packaging on Total phenol (mg/100g f.wt.) of "Canino" apricot fruits stored at $1 \pm 1^{\circ} \mathrm{C}$ followed by 5 at $18 \pm 2^{\circ} \mathrm{C}$ during 2018 and 2019 seasons

\begin{tabular}{|c|c|c|c|c|c|c|c|c|}
\hline \multirow{4}{*}{ Treatments } & \multicolumn{8}{|c|}{ Passive Modified Atmosphere Packaging } \\
\hline & \multicolumn{4}{|c|}{ Polyethylene Terephthalate (PET) } & \multicolumn{4}{|c|}{ Polypropylene Film (PPF) } \\
\hline & \multicolumn{3}{|c|}{$\begin{array}{l}\text { Days in cold storage } \\
\qquad\left(1 \pm 1^{\circ} \mathrm{C}\right)\end{array}$} & \multirow{2}{*}{$\begin{array}{l}5 \text { days } \\
\text { at } \\
18 \pm 2^{\circ} \mathrm{C}\end{array}$} & \multicolumn{3}{|c|}{$\begin{array}{l}\text { Days in cold storage } \\
\left(1 \pm 1^{\circ} \mathrm{C}\right)\end{array}$} & \multirow{2}{*}{$\begin{array}{c}5 \text { days } \\
\text { at } \\
18 \pm 2^{\circ} \mathrm{C}\end{array}$} \\
\hline & 7 & 14 & 21 & & 7 & 14 & 21 & \\
\hline \multicolumn{9}{|c|}{ Season 2018} \\
\hline Control & $0.384 \mathrm{c}$ & $0.359 \mathrm{~d}$ & $0.261 \mathrm{e}$ & $0.295 \mathrm{e}$ & $0.462 \mathrm{c}$ & $0.428 \mathrm{~d}$ & $0.317 \mathrm{e}$ & $0.314 \mathrm{e}$ \\
\hline $0.5 \mathrm{mM} \mathrm{SA}$ & $0.458 \mathrm{~b}$ & $0.419 \mathrm{c}$ & $0.346 \mathrm{~d}$ & $0.378 \mathrm{~d}$ & $0.508 \mathrm{bc}$ & $0.481 \mathrm{~d}$ & $0.403 \mathrm{~d}$ & $0.390 \mathrm{~d}$ \\
\hline $1.0 \mathrm{mM} \mathrm{SA}$ & $0.539 \mathrm{a}$ & $0.603 \mathrm{a}$ & $0.655 \mathrm{a}$ & $0.591 \mathrm{a}$ & $0.636 \mathrm{a}$ & $0.671 \mathrm{a}$ & $0.732 \mathrm{a}$ & $0.662 \mathrm{a}$ \\
\hline $1.0: 0.5 \mathrm{~A}: \mathrm{C}$ & $0.492 \mathrm{ab}$ & $0.543 a b$ & $0.578 \mathrm{~b}$ & $0.507 \mathrm{~b}$ & $0.572 a b$ & $0.595 \mathrm{bc}$ & $0.651 \mathrm{~b}$ & $0.579 \mathrm{~b}$ \\
\hline 1.0:1.0 A: C & $0.468 \mathrm{~b}$ & $0.507 \mathrm{~b}$ & $0.485 \mathrm{c}$ & $0.429 \mathrm{c}$ & $0.525 \mathrm{bc}$ & $0.554 \mathrm{c}$ & $0.569 \mathrm{c}$ & $0.485 \mathrm{c}$ \\
\hline $0.2 \%$ PEG & $0.505 a b$ & $0.516 \mathrm{~b}$ & $0.503 \mathrm{c}$ & $0.473 \mathrm{bc}$ & $0.542 \mathrm{~b}$ & $0.574 \mathrm{bc}$ & $0.611 \mathrm{bc}$ & $0.523 \mathrm{c}$ \\
\hline $0.4 \%$ PEG & $0.521 a$ & $0.577 \mathrm{a}$ & $0.625 a b$ & $0.588 \mathrm{a}$ & $0.613 \mathrm{a}$ & $0.641 \mathrm{ab}$ & $0.706 \mathrm{a}$ & $0.638 \mathrm{a}$ \\
\hline \multicolumn{9}{|c|}{ Season 2019} \\
\hline Control & $0.326 \mathrm{c}$ & $0.254 \mathrm{~d}$ & $0.217 \mathrm{e}$ & $0.211 \mathrm{e}$ & $0.387 \mathrm{c}$ & $0.322 \mathrm{~d}$ & $0.286 \mathrm{e}$ & $0.251 \mathrm{e}$ \\
\hline $0.5 \mathrm{mM} \mathrm{SA}$ & $0.388 \mathrm{~b}$ & $0.406 \mathrm{c}$ & $0.297 \mathrm{~d}$ & $0.263 \mathrm{de}$ & $0.422 \mathrm{c}$ & $0.457 \mathrm{c}$ & $0.381 \mathrm{~d}$ & $0.354 \mathrm{~d}$ \\
\hline $1.0 \mathrm{mM} \mathrm{SA}$ & $0.443 a b$ & $0.476 a b$ & $0.526 a b$ & $0.488 \mathrm{a}$ & $0.554 \mathrm{a}$ & $0.591 \mathrm{a}$ & $0.644 \mathrm{a}$ & $0.560 \mathrm{a}$ \\
\hline $1.0: 0.5 \mathrm{~A}: \mathrm{C}$ & $0.424 \mathrm{ab}$ & $0.455 a-c$ & $0.478 \mathrm{~b}$ & $0.406 \mathrm{~b}$ & $0.516 a b$ & $0.543 a b$ & $0.584 \mathrm{~b}$ & $0.485 \mathrm{~b}$ \\
\hline 1.0:1.0 A:C & $0.394 \mathrm{~b}$ & $0.423 \mathrm{bc}$ & $0.381 \mathrm{c}$ & $0.312 \mathrm{~cd}$ & $0.448 \mathrm{bc}$ & $0.479 \mathrm{bc}$ & $0.462 \mathrm{c}$ & $0.432 \mathrm{bc}$ \\
\hline $0.2 \%$ PEG & $0.408 \mathrm{~b}$ & $0.439 \mathrm{bc}$ & $0.405 \mathrm{c}$ & $0.383 \mathrm{~b}$ & $0.481 \mathrm{~b}$ & $0.515 \mathrm{bc}$ & $0.532 \mathrm{~b}$ & $0.387 \mathrm{c}$ \\
\hline $0.4 \%$ PEG & $0.467 \mathrm{a}$ & $0.506 \mathrm{a}$ & $0.542 \mathrm{a}$ & $0.467 \mathrm{a}$ & $0.569 \mathrm{a}$ & $0.608 \mathrm{a}$ & $0.652 \mathrm{a}$ & $0.554 \mathrm{a}$ \\
\hline
\end{tabular}

Values followed by the same letter (s) are not significantly different at $5 \%$ level

Initial sample recorded 0.483 and 0.406 (mg/ g f.wt) for 2018 and 2019 seasons 


\subsubsection{Total carotenoids ( $\mathrm{mg} / \mathbf{1 0 0 g}$ f.wt.)}

An evident increase in total carotenoids (Table 9) in "Canino" apricot fruits due to the applied treatments and two types of MAP during cold storage and marketing durations. All applied treatments exhibited higher values of total carotenoids than the control, but the treatments of $1.0 \mathrm{mM} \mathrm{SA}$ and the treatments combined of 1:0.5 ratio of ascorbic and citric acids were more effective than other. Total carotenoids component is important as a mean source for vitamin $A$ in apricot fruits and increasing it considered a good obtaining in this research. Also, the second type of passive MAP (polypropylene film, PPF) was more effective than first of passive MAP (polyethylene terephthalate, PET) in effecting total carotenoids in apricot fruits during cold storage and marketing durations in both seasons under studied. Salicylic acid acts as anti-ethylene persist for a lengthy time also deferment, the peaks of respiration and ethylene production, consequently reduces the ripening processes of fruits. The slowing down of the change from chlorophyll into carotenoids during cold storage by reducing the activities of the degrading enzyme chlorophyll (Cheng et al 2012).

Polyethylene glycol (PEG) is a low toxic hydrophilic alcohol polymer with high water solubility. It has been used as an inert non-penetrating osmoticum. It forms hydrogen bonds with water lowering the water manageable of cultures (Fontana et al 2008). Passive film of packages, reduce respiration rate and inhibit ripening processes which decrease the synthesis of pigments, and it may be because passive modified atmosphere packaging partially inhibits the active in polyphenol oxidase, which is related with degradation of the pigments (Moretti et al 2007).

Table 9. Effect of some post-harvest substances dipping and type of passive modified atmosphere packaging on total caroteniodes (mg/100 g f.wt) of "Canino" apricot fruits stored at $1 \pm 1^{\circ} \mathrm{C}$ followed by 5 days at $18^{\circ} \mathrm{C}$ during 2018 and 2019 seasons

\begin{tabular}{|c|c|c|c|c|c|c|c|c|}
\hline \multirow{4}{*}{ Treatments } & \multicolumn{8}{|c|}{ Passive Modified Atmosphere Packaging } \\
\hline & \multicolumn{4}{|c|}{ Polyethylene Terephthalate (PET) } & \multicolumn{4}{|c|}{ Polypropylene Film (PPF) } \\
\hline & \multicolumn{3}{|c|}{$\begin{array}{l}\text { Days in cold storage } \\
\left(1 \pm 1^{\circ} \mathrm{C}\right)\end{array}$} & \multirow{2}{*}{$\begin{array}{c}5 \text { days } \\
\text { at } \\
18 \pm 2^{\circ} \mathrm{C}\end{array}$} & \multicolumn{3}{|c|}{$\begin{array}{l}\text { Days in cold storage } \\
\qquad\left(1 \pm 1^{\circ} \mathrm{C}\right)\end{array}$} & \multirow{2}{*}{$\begin{array}{l}5 \text { days } \\
\text { at } \\
18 \pm 2^{\circ} \mathrm{C}\end{array}$} \\
\hline & 7 & 14 & 21 & & 7 & 14 & 21 & \\
\hline \multicolumn{9}{|c|}{ Season 2018} \\
\hline Control & $1.58 \mathrm{a}$ & $1.66 \mathrm{c}$ & $1.51 \mathrm{~d}$ & $1.29 \mathrm{e}$ & $1.55 \mathrm{~b}$ & $1.71 \mathrm{c}$ & $1.62 \mathrm{~d}$ & $1.43 \mathrm{e}$ \\
\hline $0.5 \mathrm{mM} \mathrm{SA}$ & $1.60 \mathrm{a}$ & $1.71 \mathrm{bc}$ & $1.74 \mathrm{bc}$ & $1.47 \mathrm{~d}$ & $1.60 \mathrm{ab}$ & $1.76 \mathrm{bc}$ & $1.73 \mathrm{c}$ & $1.64 \mathrm{~d}$ \\
\hline $1.0 \mathrm{mM} \mathrm{SA}$ & $1.65 \mathrm{a}$ & $1.78 \mathrm{a}$ & $1.81 \mathrm{ab}$ & $1.84 \mathrm{a}$ & $1.64 \mathrm{a}$ & $1.86 \mathrm{a}$ & $1.98 \mathrm{a}$ & $1.94 \mathrm{a}$ \\
\hline $1.0: 0.5 \mathrm{~A}: \mathrm{C}$ & $1.63 \mathrm{a}$ & $1.73 a b$ & $1.85 \mathrm{a}$ & $1.72 \mathrm{~b}$ & $1.63 \mathrm{a}$ & $1.81 \mathrm{ab}$ & $b$ & $1.83 \mathrm{~b}$ \\
\hline 1.0:1.0 A: C & $1.60 \mathrm{a}$ & $1.68 \mathrm{bc}$ & $1.72 \mathrm{bc}$ & $1.60 \mathrm{c}$ & $1.59 a b$ & $1.80 \mathrm{ab}$ & $1.87 \mathrm{~b}$ & $1.71 \mathrm{~cd}$ \\
\hline $0.2 \%$ PEG & $1.57 \mathrm{a}$ & $1.70 \mathrm{bc}$ & $1.66 \mathrm{c}$ & $1.64 \mathrm{bc}$ & $1.61 \mathrm{ab}$ & $1.78 \mathrm{bc}$ & $1.80 \mathrm{c}$ & $1.77 \mathrm{bc}$ \\
\hline $0.4 \%$ PEG & $1.61 \mathrm{a}$ & $1.74 \mathrm{ab}$ & $1.79 \mathrm{ab}$ & $1.81 \mathrm{a}$ & $1.63 \mathrm{a}$ & $1.82 \mathrm{ab}$ & $1.91 \mathrm{ab}$ & $1.86 \mathrm{ab}$ \\
\hline \multicolumn{9}{|c|}{ Season 2019} \\
\hline Control & $1.66 \mathrm{a}$ & $1.72 \mathrm{c}$ & $1.63 \mathrm{~d}$ & $1.41 \mathrm{e}$ & $1.69 \mathrm{a}$ & $1.75 \mathrm{c}$ & $1.70 \mathrm{e}$ & $1.57 \mathrm{e}$ \\
\hline $0.5 \mathrm{mM} \mathrm{SA}$ & $1.63 \mathrm{a}$ & $1.78 \mathrm{ab}$ & $1.74 \mathrm{c}$ & $1.57 \mathrm{~d}$ & $1.63 \mathrm{~b}$ & $1.80 \mathrm{bc}$ & $1.78 \mathrm{~d}$ & $1.70 \mathrm{~d}$ \\
\hline $1.0 \mathrm{mM} \mathrm{SA}$ & $1.68 \mathrm{a}$ & $1.84 \mathrm{a}$ & $1.93 \mathrm{a}$ & $1.89 \mathrm{a}$ & $1.67 \mathrm{ab}$ & $1.89 \mathrm{a}$ & $2.03 \mathrm{a}$ & $2.07 \mathrm{a}$ \\
\hline $1.0: 0.5 \mathrm{~A}: \mathrm{C}$ & $1.60 \mathrm{a}$ & $1.77 \mathrm{bc}$ & $1.81 \mathrm{bc}$ & $1.76 \mathrm{~b}$ & $1.66 \mathrm{ab}$ & $1.83 \mathrm{ab}$ & $1.91 \mathrm{bc}$ & $1.90 \mathrm{bc}$ \\
\hline 1.0:1.0 A: C & $1.63 \mathrm{a}$ & $1.75 \mathrm{bc}$ & $1.74 \mathrm{c}$ & $1.61 \mathrm{~cd}$ & $1.61 \mathrm{~b}$ & $1.83 a b$ & $1.87 \mathrm{c}$ & $1.75 \mathrm{c}$ \\
\hline $0.2 \%$ PEG & $1.62 \mathrm{a}$ & $1.83 \mathrm{a}$ & $1.77 \mathrm{c}$ & $1.65 \mathrm{c}$ & $1.64 \mathrm{ab}$ & $1.85 a b$ & $1.93 \mathrm{bc}$ & $1.83 \mathrm{c}$ \\
\hline $0.4 \%$ PEG & $1.67 \mathrm{a}$ & $1.80 \mathrm{ab}$ & $1.87 \mathrm{ab}$ & $1.82 \mathrm{ab}$ & $1.67 \mathrm{ab}$ & $1.87 \mathrm{a}$ & $1.96 \mathrm{ab}$ & $1.95 \mathrm{~b}$ \\
\hline
\end{tabular}

Values followed by the same letter (s) are not significantly different at $5 \%$ level

Initial sample recorded 1.45 and 1.58 \& $\mathrm{mg} / 100 \mathrm{~g}$ f.wt) for 2018 and 2019 seasons 


\section{Synergistic Effect of Some Post-harvest Treatments and Passive Modified Atmosphere Packaging Conditions on Cold Storability of "Canino "Apricot Fruits}

\subsection{Physiological attributes}

\subsubsection{Peroxidase and Catalase Enzymes activi-} ties: ( $\mu$ mol min $\mathrm{mg}^{-1} \mathrm{mg}^{-1}$ rotein)

Data in Table 10 show that both peroxidase and catalase enzymes activates contents greatly affected by both studied factors during storage durations Regarding peroxidase enzyme activity, it is clear that an evident reduction with control and 0.5 mM SA treatments were noticed either after cold storage or marketing periods. However, all other applied treatments exhibited higher values of peroxidase enzyme Regarding peroxidase enzyme activity and the treatments of $1.0 \mathrm{mM} \mathrm{SA}$ and $0.4 \%$ PEG were more effective and recording the highest values in this respect without significant differences between them

On the other side, the second type of passive modified atmosphere packaging (polypropylene film, PPF) was superior than the first type (polyethylene terephthalate, PET) in recording highest values of peroxidase enzyme activity in all samples in both seasons. Peroxidase enzyme values activity showed that initial sample was $13.54 \mu \mathrm{mol}$ min-1 mg-1 protein, after finished from cold storage duration reduced to 10.53 in untreated fruits whereas increased to 17.39 with 0.4 PEG treatment during the first season. Catalase enzyme activity followed similar trend to those found in peroxidase enzyme. However, all applied treatments except $0.5 \mathrm{mM} \mathrm{SA}$ increased catalase enzyme activity than control either after finished from cold storage or marketing durations. Also, the second type of passive MAP was more effective than first type in recording high values of catalase enzyme in all cases. For instance, catalase enzyme activity was $0.97 \mu \mathrm{mol}$ min-1 mg-1 protein reduced to $0.81 \mu \mathrm{mol} \mathrm{min-1} \mathrm{mg-}$ 1 protein in the control compared to $1.33 \mu \mathrm{mol}$ min-1 mg-1 protein in $0.4 \%$ PEG. The great effect to applied treatments and the second type of passive MAP (polypropylene film, PPF) on increasing peroxidase and catalase enzymes activity are correlated with preservation on fruit quality during storage and minimize physiological disorders incidence.

The reason for oxidation of lipid membranes is the presence of reactive oxygen species that cause severe damage to the cell membrane, which leads to creating in fruits senescence (Karuppanapandian et al 2011). There have been many defensive enzymes that eradicated active oxygen in plant tissues for example peroxidase and catalase enzymes which play a significant preventive function in opposition to oxidative damages induced caused by reactive oxygen species and gives cellular resistance towards the toxicity of $\mathrm{H} 2 \mathrm{O} 2$ (Sharma et al 2012). The oxide radicals are changing into $\mathrm{H} 2 \mathrm{O} 2$ in end result of SOD activity enzyme and the identical is disintegrating into water and oxygen by activities peroxidase and catalase enzymes. There is a close relationship between the activity of antioxidant enzymes, ripening process so fruits senescence (Tareen et al 2012).

In this respect, Mohamed et al (2016), treated fruits with salicylic acid have shown a persistent rise in antioxidant activity during cold storage than control fruits. Dipping fruits of salicylic acid have showed an increase activity of antioxidant enzymes. Ascorbic acid is also, a main metabolite in plants that have antioxidant characteristic. It is possible that, catalase action raises the level of ascorbic acid and thus increases in dealing with oxidative stress (Dixit et al 2001). Yoruk et al (2005) proposed that, ascorbic acid is may promote catalase and peroxidase enzymes activity by lowering $\mathrm{pH}$ of the cells .Polyethylene glycol (PEG), soluble in water, nontoxic, and safe for coating .Used PEG may impact, the water vapor permeability of the coating, this pretreatment of PEG increases levels of oxidative enzymes catalase and peroxidase (Anan et al 2007). 
Table 10. Effect of some post-harvest substances dipping and type of passive modified atmosphere packaging on peroxidase and catalase enzymes activities ( $\mu \mathrm{mol} \mathrm{min} \mathrm{mg}^{-1} \mathrm{mg}^{-1}$ protein) of "Canino" apricot fruits stored at $0 \pm 1^{\circ} \mathrm{C}$ followed by 5 days at $18^{\circ} \mathrm{C}$ during 2018 and 2019 seasons

\begin{tabular}{|c|c|c|c|c|c|c|c|c|}
\hline \multirow{3}{*}{ Treatments } & \multicolumn{4}{|c|}{ Peroxidase enzyme } & \multicolumn{4}{|c|}{ Catalase enzyme } \\
\hline & \multicolumn{2}{|c|}{\begin{tabular}{|c|} 
Polyethylene \\
Terephthalate (PET) \\
\end{tabular}} & \multicolumn{2}{|c|}{$\begin{array}{c}\text { Polypropylene Film } \\
\text { (PPF) }\end{array}$} & \multicolumn{2}{|c|}{\begin{tabular}{|c|} 
Polyethylene \\
Terephthalate (PET)
\end{tabular}} & \multicolumn{2}{|c|}{$\begin{array}{c}\text { Polypropylene Film } \\
\text { (PPF) }\end{array}$} \\
\hline & $\begin{array}{c}\text { Out of } \\
\text { cold } \\
\text { storage }\end{array}$ & \begin{tabular}{|c|}
5 days \\
Marketale \\
Life
\end{tabular} & $\begin{array}{c}\text { Out of } \\
\text { cold } \\
\text { storage }\end{array}$ & $\begin{array}{c}5 \text { days } \\
\text { Marketabe } \\
\text { Life }\end{array}$ & \begin{tabular}{|c|} 
Out of \\
cold \\
storage
\end{tabular} & $\begin{array}{c}5 \text { days } \\
\text { Marketae } \\
\text { Life }\end{array}$ & \begin{tabular}{|c|} 
Out of \\
cold \\
storage
\end{tabular} & $\begin{array}{c}5 \text { days } \\
\text { Marketabe } \\
\text { Life }\end{array}$ \\
\hline \multicolumn{9}{|c|}{2018 Season } \\
\hline Control & $10.53 \mathrm{e}$ & & $7 \mathrm{e}$ & $10.84 \mathrm{e}$ & $d$ & & $\mathrm{e}$ & $d$ \\
\hline $0.5 \mathrm{mM} \mathrm{SA}$ & $12.37 \mathrm{~d}$ & & & & & & & \\
\hline $1.0 \mathrm{mM} \mathrm{SA}$ & $17.13 \mathrm{a}$ & & & & & & & \\
\hline $1.0: 0.5 \mathrm{~A}: \mathrm{C}$ & $15.45 \mathrm{~b}$ & $\mathrm{~b}$ & & & & & $9 \mathrm{~b}$ & \\
\hline 1.0:1.0 A: C & $14.77 \mathrm{bc}$ & & & & & & & \\
\hline $0.2 \%$ PEG & $14.38 \mathrm{c}$ & 5 bc & $72 \mathrm{~cd}$ & & $1.02 \mathrm{bc}$ & $3 \mathrm{~cd}$ & $1.17 \mathrm{bc}$ & $5 \mathrm{c}$ \\
\hline $0.4 \%$ PEG & $16.61 \mathrm{a}$ & $39 \mathrm{a}$ & $18.75 \mathrm{a}$ & $3 a b$ & $1.33 \mathrm{a}$ & $5 \mathrm{a}$ & $1.42 \mathrm{a}$ & \\
\hline \multicolumn{9}{|c|}{2019 Season } \\
\hline & & & & & & & & \\
\hline $0.5 \mathrm{mM} \mathrm{SA}$ & $11.05 \mathrm{~d}$ & $3 d$ & & & $0.87 \mathrm{e}$ & $0.77 \mathrm{~d}$ & $0.98 \mathrm{~d}$ & $d$ \\
\hline $1.0 \mathrm{mM} \mathrm{SA}$ & $15.74 \mathrm{a}$ & & & & & & $1.41 \mathrm{a}$ & \\
\hline $1.0: 0.5 \mathrm{~A}: \mathrm{C}$ & $14.42 \mathrm{~b}$ & $13.90 \mathrm{~b}$ & $16.21 \mathrm{bc}$ & $16.66 \mathrm{~b}$ & $1.05 \mathrm{bc}$ & $0.96 \mathrm{~b}$ & $1.23 \mathrm{~b}$ & $1.15 b$ \\
\hline 1.0:1.0 A: C & $12.58 \mathrm{c}$ & $10.86 \mathrm{~d}$ & $15.54 \mathrm{c}$ & $13.21 \mathrm{c}$ & $0.96 \mathrm{~cd}$ & $0.84 \mathrm{c}$ & $1.05 \mathrm{~cd}$ & $0.97 \mathrm{c}$ \\
\hline $0.2 \%$ PEG & $13.34 \mathrm{c}$ & $12.22 \mathrm{c}$ & $14.97 \mathrm{c}$ & $14.07 \mathrm{c}$ & $0.98 \mathrm{~cd}$ & $0.90 \mathrm{bc}$ & $1.12 \mathrm{bc}$ & $0.93 \mathrm{~cd}$ \\
\hline $0.4 \%$ PEG & $15.07 \mathrm{ab}$ & $15.74 \mathrm{a}$ & $17.03 \mathrm{~b}$ & $17.82 \mathrm{~b}$ & $1.11 \mathrm{ab}$ & $1.04 \mathrm{a}$ & $1.36 \mathrm{a}$ & $1.18 b$ \\
\hline
\end{tabular}

Values followed by the same letter (s) are not significantly different at $5 \%$ level

Initial sample for peroxidase enzyme recorded 13.54 and 11.95 \& catalase enzyme recorded 0.97 and 0.8611 ( $\mu \mathrm{mol}$ min$1 \mathrm{mg}-1$ protein) for 2018 and 2019 seasons

\subsubsection{Electrolyte leakage \% (EC)}

As it shown in Table 11, electrolyte leakage \% greatly affected with both studied factors during cold storage and marketing periods. It is well known that, is a good parameter to measure quality preservation of fruits during cold storage. However, all applied treatments greatly decreased EC\% than control during cold storage at $1 \pm 1^{\circ} \mathrm{C}$ for 21 days followed by 5 days at $18 \pm 2^{\circ} \mathrm{C}$ as a marketing period. The treatments of $1.0 \mathrm{mM} \mathrm{SA}$ and $0.4 \%$ PEG were more effective than other treatments in recording the least values of EC\%. It could be concluded that as EC\% decreased, the quality of apricot fruits are increased, due to that the increase of electrolyte leakage \% mean that fruits tissue become more soft and cell sap become more succulence and leakage out of cells .The second type of passive MAP (polypropylene film, PPF) was more effective than first type (polyethylene terephthalate, PET) in recording least values of EC\% during cold storage and marketing periods in both seasons.
Khademi and Ershadi (2013) explained that the reduction of salicylic acid treatments and the activity of enzymes led to cell wall degradation, which increases the post-harvest cycle and delay fruit ripening and inducing systemic resistances towards postharvest pathogen which prolong storability of fruits with greater antioxidant recreation that activates natural protection mechanism. PEG is a flexible, water-soluble polymer used in the manufacture, which has a high osmotic pressure and likewise, specific interactions with biological materials. These characteristic make PEG one of the most useful materials for applying osmotic pressure experiments in bio membranes and biochemistry. It is also used as a multi-surface coating in both aqueous and nonaqueous environments. (Wenande and Garvey 2016). Water satiated atmosphere inside the packages controlled water loss and delayed senescence in the absence of water stress and thereby e prolonged postharvest longevity of fruits. Besides, modified atmosphere packaging can efficaciously 


\section{Synergistic Effect of Some Post-harvest Treatments and Passive Modified Atmosphere Packaging Conditions on Cold Storability of "Canino "Apricot Fruits}

Table 11. Effect of some post-harvest substances dipping and type of passive modified atmosphere packaging on electrolyte leakage \% (EC) of "Canino" apricot fruits stored at $1 \pm 1^{\circ} \mathrm{C}$ followed by 5 days at $18 \pm 2^{\circ} \mathrm{C}$ during 2018 and 2019 seasons

\begin{tabular}{|c|c|c|c|c|c|c|c|c|}
\hline \multirow{4}{*}{ Treatments } & \multicolumn{8}{|c|}{ Passive Modified Atmosphere Packaging } \\
\hline & \multicolumn{4}{|c|}{ Polyethylene Terephthalate (PET) } & \multicolumn{4}{|c|}{ Polypropylene Film (PPF) } \\
\hline & \multicolumn{3}{|c|}{$\begin{array}{l}\text { Days in cold storage } \\
\left(1 \pm 1^{\circ} \mathrm{C}\right)\end{array}$} & \multirow{2}{*}{$\begin{array}{c}5 \text { days } \\
\text { at } \\
18 \pm 2^{\circ} \mathrm{C}\end{array}$} & \multicolumn{3}{|c|}{$\begin{array}{l}\text { Days in cold storage } \\
\left(1 \pm 1^{\circ} \mathrm{C}\right)\end{array}$} & \multirow{2}{*}{$\begin{array}{c}5 \text { days } \\
\text { at } \\
18 \pm 2^{\circ} \mathrm{C}\end{array}$} \\
\hline & 7 & 14 & 21 & & 7 & 14 & 21 & \\
\hline \multicolumn{9}{|c|}{2018 Season } \\
\hline Control & $32.7 \mathrm{ab}$ & $46.9 \mathrm{a}$ & $59.8 a$ & $74.3 \mathrm{a}$ & $31.0 \mathrm{a}$ & $40.8 \mathrm{a}$ & $47.4 \mathrm{a}$ & $66.1 \mathrm{a}$ \\
\hline $0.5 \mathrm{mM}$ SA & $33.1 \mathrm{ab}$ & $42.1 \mathrm{~b}$ & $54.4 \mathrm{~b}$ & $71.8 \mathrm{a}$ & $30.6 \mathrm{ab}$ & $39.8 \mathrm{ab}$ & $44.1 \mathrm{~b}$ & $62.4 \mathrm{~b}$ \\
\hline $1.0 \mathrm{mM} \mathrm{SA}$ & $31.6 \mathrm{~b}$ & $39.0 \mathrm{~cd}$ & $46.3 \mathrm{~d}$ & $52.7 \mathrm{~d}$ & $29.3 \mathrm{bc}$ & $35.1 \mathrm{c}$ & $38.2 \mathrm{de}$ & $43.0 \mathrm{e}$ \\
\hline $1.0: 0.5 \mathrm{~A}: \mathrm{C}$ & $33.4 \mathrm{ab}$ & $41.4 \mathrm{bc}$ & $49.4 \mathrm{c}$ & $60.1 \mathrm{c}$ & $30.1 \mathrm{ab}$ & $35.9 \mathrm{c}$ & $40.3 \mathrm{c}$ & $48.9 \mathrm{~d}$ \\
\hline 1.0:1.0 A: C & $34.7 \mathrm{a}$ & $43.2 \mathrm{~b}$ & $51.3 \mathrm{bc}$ & $64.5 \mathrm{~b}$ & $29.6 \mathrm{bc}$ & $38.6 \mathrm{ab}$ & $44.9 \mathrm{ab}$ & $57.2 \mathrm{c}$ \\
\hline $0.2 \%$ PEG & $32.9 \mathrm{ab}$ & $42.5 \mathrm{~b}$ & $52.0 \mathrm{bc}$ & & $30.4 \mathrm{ab}$ & $37.4 \mathrm{bc}$ & $42.7 \mathrm{c}$ & $56.5 \mathrm{c}$ \\
\hline $0.4 \%$ PEG & $31.4 \mathrm{~b}$ & $37.8 \mathrm{~d}$ & $45.6 \mathrm{~d}$ & $54.6 \mathrm{~d}$ & $28.6 \mathrm{c}$ & $34.7 \mathrm{c}$ & $36.7 \mathrm{e}$ & $46.3 d$ \\
\hline \multicolumn{9}{|c|}{2019 Season } \\
\hline Control & $36.0 \mathrm{ab}$ & $47.7 \mathrm{a}$ & $57.6 \mathrm{a}$ & $70.6 \mathrm{a}$ & $34.2 \mathrm{a}$ & $41.1 \mathrm{a}$ & $50.3 \mathrm{a}$ & $64.9 \mathrm{a}$ \\
\hline $0.5 \mathrm{mM} \mathrm{SA}$ & $35.6 \mathrm{ab}$ & $43.5 \mathrm{~b}$ & $52.9 \mathrm{~b}$ & $67.8 \mathrm{a}$ & $33.1 \mathrm{ab}$ & $39.2 \mathrm{ab}$ & $46.6 \mathrm{~b}$ & $61.5 \mathrm{~b}$ \\
\hline $1.0 \mathrm{mM} \mathrm{SA}$ & $35.0 \mathrm{ab}$ & $38.5 \mathrm{c}$ & $45.3 d$ & $54.2 \mathrm{e}$ & $31.6 \mathrm{c}$ & $35.4 \mathrm{~d}$ & $38.9 \mathrm{~d}$ & $46.4 \mathrm{e}$ \\
\hline $1.0: 0.5 \mathrm{~A}: \mathrm{C}$ & $34.6 \mathrm{~b}$ & $43.6 \mathrm{~b}$ & $49.1 \mathrm{c}$ & $59.4 \mathrm{~cd}$ & $33.0 \mathrm{ab}$ & $37.3 \mathrm{~cd}$ & $43.5 \mathrm{c}$ & $55.2 \mathrm{c}$ \\
\hline 1.0:1.0 A: C & $36.7 \mathrm{a}$ & $42.9 \mathrm{~b}$ & $53.8 \mathrm{~b}$ & $61.4 \mathrm{bc}$ & $33.3 \mathrm{ab}$ & $39.8 \mathrm{ab}$ & $46.1 \mathrm{bc}$ & $54.3 \mathrm{c}$ \\
\hline $0.2 \%$ PEG & $35.2 \mathrm{ab}$ & $41.4 \mathrm{bc}$ & $50.4 \mathrm{bc}$ & $63.9 \mathrm{~b}$ & $32.5 \mathrm{bc}$ & $38.0 \mathrm{bc}$ & $45.0 \mathrm{bc}$ & $52.8 \mathrm{~cd}$ \\
\hline $0.4 \%$ PEG & $34.2 \mathrm{~b}$ & $39.1 \mathrm{c}$ & $47.5 \mathrm{~cd}$ & $56.7 \mathrm{de}$ & $32.0 \mathrm{bc}$ & $37.2 \mathrm{~cd}$ & $40.2 \mathrm{~d}$ & $49.7 d$ \\
\hline
\end{tabular}

Values followed by the same letter (s) are not significantly different at $5 \%$ level Initial sample recorded 27.1 and $30.3 \%$ (EC) for 2018 and 2019 seasons

inhibit the cell permeability increasing, for this reason the fruit firmness was maintained during storage (Oliveira et al 2015). However, Attica (2005) found that $\mathrm{CO}_{2}$ enhanced firmness of fruits, because it increases the strength of the bonds between the cells and changes in conductivity. In addition, changes in $\mathrm{pH}$ are related to the $\mathrm{CO} 2$ stability-enhancing mechanism (Shehata et al 2009).

\subsubsection{Respiration rate ( $\mathrm{mg} \mathrm{CO} / \mathrm{kg}$ herb/hr.)}

Data in Table 12 show that the respiration rate was deceased after 7 days them in cold storage and during marketing period. However, all used treatments greatly decreased respiration rate than control after 7,14 and 21 days of cold storage at $1 \pm 1^{\circ} \mathrm{C}$. followed by 5 days at $18 \pm 2^{\circ} \mathrm{C}$ as a marketing assimilation. The treatments of $1.0 \mathrm{mM} \mathrm{SA}$ and $0.4 \%$ PEG were effective than other treatments in recording less values of respiration rate during cold storage at $1 \pm 1^{\circ} \mathrm{C}$. followed by marketing period at $18 \pm 2^{\circ} \mathrm{C}$ Respiration rate data recorded by the second type of passive MAP were less than those recoded by the first type of passive MAP regardless of the used treatments. The increase of respiration rate led to consumption dry matter and increase of weight loss \% "Canino" apricot fruits which previously discussed.

Kato-Noguchi and Watada (1997) located that the use of citric acid decreased the respiratory rate. It is also considered one of the factors that control the metabolism of the respiratory system cell, as it inhibits the accumulation of cytosolic pyruvate kinase activity, which raises the level of phosphoinol pyruvate in the cytosol and in turn reduces the conversion of fructose-6-phosphate to fructose-1.6-biophosphate, thus lowering glycolysis. Besides, it lowers the cellular $\mathrm{pH}$ and thus directly affects the activity of the phosphofructokinase enzyme. 
Table 12. Effect of some post-harvest substances dipping and type of passive modified atmosphere packaging on respiration rate $\left(\mathrm{mg} \mathrm{CO} / \mathrm{kg}\right.$ fruits / $\mathrm{hr}$ ) of "Canino" apricot fruits stored at $1 \pm 1^{\circ} \mathrm{C}$ followed by 5 days at $18 \pm 2^{\circ} \mathrm{C}$ during 2018 and 2019 seasons

\begin{tabular}{|c|c|c|c|c|c|c|c|c|}
\hline \multirow{4}{*}{ Treatments } & \multicolumn{8}{|c|}{ Passive Modified Atmosphere Packaging } \\
\hline & \multicolumn{4}{|c|}{ Polyethylene Terephthalate (PET) } & \multicolumn{4}{|c|}{ Polypropylene Film (PPF) } \\
\hline & \multicolumn{3}{|c|}{$\begin{array}{l}\text { Days in cold storage } \\
\qquad\left(1 \pm 1^{\circ} \mathrm{C}\right)\end{array}$} & \multirow{2}{*}{$\begin{array}{c}5 \text { days } \\
\text { at } \\
18 \pm 2^{\circ} \mathrm{C}\end{array}$} & \multicolumn{3}{|c|}{$\begin{array}{l}\text { Days in cold storage } \\
\qquad\left(1 \pm 1^{\circ} \mathrm{C}\right)\end{array}$} & \multirow{2}{*}{$\begin{array}{c}5 \text { days } \\
\text { at } \\
18 \pm 2^{\circ} \mathrm{C} \\
\end{array}$} \\
\hline & 7 & 14 & 21 & & 7 & 14 & 21 & \\
\hline \multicolumn{9}{|c|}{2018 Season } \\
\hline Control & $3.14 \mathrm{a}$ & $5.25 \mathrm{a}$ & $8.11 \mathrm{a}$ & $13.15 \mathrm{a}$ & $2.26 \mathrm{a}$ & $3.75 \mathrm{a}$ & $6.08 \mathrm{a}$ & $11.35 \mathrm{a}$ \\
\hline $0.5 \mathrm{mM} \mathrm{SA}$ & $2.92 \mathrm{ab}$ & $4.70 \mathrm{a}$ & $7.23 \mathrm{~b}$ & $12.56 \mathrm{a}$ & $2.14 a b$ & $3.31 \mathrm{~b}$ & $5.52 \mathrm{~b}$ & $10.17 \mathrm{~b}$ \\
\hline $1.0 \mathrm{mM} \mathrm{SA}$ & $2.32 \mathrm{c}$ & $2.87 \mathrm{~d}$ & $4.38 \mathrm{~d}$ & $8.42 \mathrm{~d}$ & $1.79 \mathrm{c}$ & $2.44 \mathrm{~d}$ & $3.82 \mathrm{e}$ & $6.20 \mathrm{f}$ \\
\hline $1.0: 0.5 \mathrm{~A}: \mathrm{C}$ & $2.68 \mathrm{bc}$ & $3.36 \mathrm{~b}-\mathrm{d}$ & $5.03 \mathrm{~cd}$ & $9.28 \mathrm{~cd}$ & $1.93 \mathrm{bc}$ & $2.81 \mathrm{~cd}$ & $4.57 d$ & $7.91 \mathrm{de}$ \\
\hline 1.0:1.0 A: C & $2.81 \mathrm{ab}$ & $3.59 \mathrm{bc}$ & $5.66 \mathrm{c}$ & $11.15 \mathrm{~b}$ & $2.07 \mathrm{ab}$ & $3.13 \mathrm{bc}$ & $4.92 \mathrm{~cd}$ & $9.04 \mathrm{c}$ \\
\hline $0.2 \%$ PEG & $2.76 \mathrm{ab}$ & $3.85 \mathrm{~b}$ & $9 \mathrm{~b}$ & $3 b$ & $1.91 \mathrm{bc}$ & $3.05 \mathrm{bc}$ & $5.14 \mathrm{bc}$ & $8.63 \mathrm{~cd}$ \\
\hline $0.4 \%$ PEG & $2.56 \mathrm{bc}$ & $3.14 \mathrm{~cd}$ & $4.79 \mathrm{~d}$ & $9.52 \mathrm{c}$ & $1.86 \mathrm{c}$ & $2.53 \mathrm{~d}$ & $4.03 \mathrm{e}$ & $7.19 \mathrm{e}$ \\
\hline \multicolumn{9}{|c|}{2019 Season } \\
\hline Control & $3.73 \mathrm{a}$ & $5.48 \mathrm{a}$ & $8.48 \mathrm{a}$ & $14.59 \mathrm{a}$ & $2.72 \mathrm{a}$ & $4.18 \mathrm{a}$ & $6.36 \mathrm{a}$ & $12.71 \mathrm{a}$ \\
\hline $0.5 \mathrm{mM} \mathrm{SA}$ & $3.45 \mathrm{a}$ & $5.06 \mathrm{a}$ & $7.76 a b$ & $14.34 \mathrm{a}$ & $2.68 \mathrm{a}$ & $3.62 \mathrm{~b}$ & $5.66 \mathrm{~b}$ & $11.10 \mathrm{~b}$ \\
\hline $1.0 \mathrm{mM} \mathrm{SA}$ & $2.65 \mathrm{bc}$ & $3.21 \mathrm{~d}$ & $5.11 \mathrm{~d}$ & $9.24 \mathrm{~d}$ & $1.97 \mathrm{c}$ & $2.69 \mathrm{~cd}$ & $3.53 \mathrm{~d}$ & $7.77 \mathrm{e}$ \\
\hline $1.0: 0.5 \mathrm{~A}: \mathrm{C}$ & $2.74 \mathrm{bc}$ & $3.97 \mathrm{bc}$ & $6.43 c$ & $11.10 \mathrm{c}$ & $2.50 \mathrm{ab}$ & $2.94 \mathrm{~cd}$ & $4.11 \mathrm{~cd}$ & $8.45 \mathrm{de}$ \\
\hline 1.0:1.0 A: C & $3.27 \mathrm{a}$ & $4.56 \mathrm{~b}$ & $7.19 \mathrm{bc}$ & $12.51 \mathrm{~b}$ & $2.38 b$ & $3.14 \mathrm{bc}$ & $4.63 \mathrm{c}$ & $9.78 \mathrm{c}$ \\
\hline $0.2 \%$ PEG & $3.16 a b$ & $4.14 \mathrm{bc}$ & $6.74 \mathrm{c}$ & $13.06 \mathrm{~b}$ & $2.21 \mathrm{bc}$ & $2.88 \mathrm{~cd}$ & $4.45 c$ & $9.22 \mathrm{~cd}$ \\
\hline $0.4 \%$ PEG & $2.60 \mathrm{c}$ & $3.56 \mathrm{~cd}$ & $5.62 \mathrm{~d}$ & $10.14 \mathrm{~cd}$ & $2.11 \mathrm{c}$ & $2.51 \mathrm{~d}$ & $3.82 \mathrm{~d}$ & $8.06 \mathrm{e}$ \\
\hline
\end{tabular}

Values followed by the same letter (s) are not significantly different at $5 \%$ level

Initial sample recorded 6.79 and 7.31 (mg CO2 / kg / hr) for 2018 and 2019 seasons

\section{Conclusion}

From the obtained data it could be successfully stored \% "Canino" apricot fruits at $1 \pm 1^{\circ} \mathrm{C}$. For 21 days followed by 5 days at $18 \pm 2^{\circ} \mathrm{C}$ as a marketing assimilation. The quality of "Canino" apricot fruits are increased, with $1.0 \mathrm{mM} \mathrm{SA}$, combined of 1:0.5 ratio of ascorbic and citric acids and $0.4 \%$ PEG treatments. In addition, polypropylene film, as type of passive modified atmosphere packaging was more effective in effecting storage of "Canino" apricot fruits.

\section{Reference}

A.O.A.C. (2005) Official Methods of the Analysis of AOAC. International18th Edition, Published by AOAC International. Maryland, USA pp. 2087722417.

Adel, D; Awad, A (2012) Postharvest salicylic acid treatment reduces chilling injury of 'Taify' cactus pear fruit during cold storage. Journal of Food, Agriculture \& Environment 10, 120-124.
Afsaneh, A; Alireza, F; Mohammadreza, A; Ali, S (2018) Foliar application of ascorbic and citric acids enhanced 'Red Spur' apple fruit quality, bioactive compounds and antioxidant activity. Physiology and Molecular Biology of Plants 24, 433-440.

Akbudak B (2008) Effect of polypropylene and polyvinyl chloride plastic film packaging materials on the quality of ryalova Charleston pepper (Capsicum annuum L.) during storage. Food Sci Technol Res 14, 5-11.

Alejandra, ME; Maria, S; Daniel, V; Domingo, MR; Salvador, C; Pedro, JZ (2017) Enhancement of Antioxidant Systems and Storability of Two Plum Cultivars by Preharvest Treatments with Salicylates. Int J Mol Sci 18, 1911.

Allende, A; Marin, A; Buendia, B; Tomas, F (2007) Impact of combined postharvest treat-ments (UV-C light, gaseous $\mathrm{O} 3$, super atmos-pheric $\mathrm{O} 2$ and high Co2) on health promoting compounds and shelf-life of strawberries. Postharvest Biology and Technology 46, 201-211. 


\section{Synergistic Effect of Some Post-harvest Treatments and Passive Modified Atmosphere Packaging Conditions on Cold Storability of "Canino "Apricot Fruits}

Al-Taha, HA (2013) Effect of shock and gradual drought by PEG on callus growth and proline accumulation in sour orange (Citrus $\mathrm{x}$ aurantium). $A A B$ Bioflux 5, 77-83.

Anan, M; Limmatvapirat, S; Nunthanid, J; Wanawongthai, C (2007) Effect of Salts and Plasticizers on Stability of Shellac Lapisan. Journal of Agriculturaland Food Chemistry 55, 687-692.

Asghari, M; Rashid, HA (2015) Interaction effects of salicylic acid and methyl jasmonate on total antioxidant content, catalase and peroxidase enzymes activity in Sabrosa strawberry fruit during storage. Sci Hort 197, 490-495.

Attia, AA (2005) Effect of modified atmosphere storage on keeping quality of strawberry fruits and transplants. Thesis PhD. Faculty of Ain Shams University, Egypt, Cairo, 86 p.

Bal, E; Celik, S (2010) The effects of postharvest treatments of salicylic acid and potassium permanganate on the storage of kiwifruit. Bulg J Agric Sci $16,576-584$.

Cai, C; Xu, CJ; Li, X; Ferguson, I (2006) Accumulation of lignin in relation to change in activities of lignification enzymes in loquat fruit flesh after harvest. Postharvest Biol Technol 40, 163-169.

Cao, JK; Zhao, YM; Wang, M (2009) Effects of 1Methylcyclopropene on apricot fruit quality, decay, and on physiological and biochemical metabolism during shelf-life following long-term cold storage," Journal of Horticultural Science \& Biotechnology 84, 672-676.

Cheng, Y; Dong, Y; Yan, H; Ge, W; Shen, C; Guan, J; Liu, L; Zhang, Y (2012) Effects of 1-MCP on chlorophyll degradation pathway-associated genes expression and chloroplast ultrastructure during the peel yellowing of Chinese pear fruits in storage. Food Chemistry 135, 415-422.

Clairbone, A (1985) Catalase activity. In: Greenwald, R. (Edition), Handbook of methods for oxygen radical research. CRC Press, Boca Raton, FL pp 283-284

Daniel, HD; George, CM (1972) Peach seed dormancy in relation to indogenous inhibition and applied growth substances. J of American Society of Horticulture Science, 97, 651-654.

Dixit, V; Pandey, V; Shyam, R (2001) Differential antioxidative responses to cadmium in roots and leaves of pea (Pisum sativum). J Exp Bot 52, 11011109.
El-Hifny, IM; El-Sayed, MA (2011) Response of sweet pepper plant growth and productivity to application of ascorbic acid and biofertilizer under saline conditions. Aust J Basic Appl Sci 5, 1273-1283.

El-Kobisy, DS; Kady, KA; Medani, RA (2005) Response of pea plant Pisum sativum L. to treatment with ascorbic acid. Egypt J App/ Sci 20, 36-50.

Ezzat, A (2014) Pomological evaluation of apricot cultivars and the roles of postharvest application of salicylic acid and methyl jasmonate on stress resistance. PhD. Thesis. University of Deprecen, Hungry.

Fontana, A; Spolaore, B; Mero, A; Veronese, FM (2008) Site-specific modification and PEGylation of pharmaceutical proteins mediated by transglutaminase. Adv Drug Deliv Rev 60, 13-28.

Goto, M; Minimize, T; Iwata, T (2011) Influence of cultivars and harvest maturity on the chilling sensitivity and on the effect of cold-shock treatment for preventing the chilling injury in Mume (Japanese apricot Prunus mume Sieb. et Zucc.) fruits," Journal of Japanese Institute of Cold Chain 12, 17-24.

Hagenmaier, RD (2005) A comparison of ethane, ethylene and $\mathrm{CO} 2$ peel permeance for fruit with different coatings Postharvest Biol Technol 37, 56-64.

Herzog, V; Fahimi, H (1973) Determination of the activity of peroxidase. Analytical Biochemistry 55, 554-562.

Hooper, L; Cassidy, A (2006) A review of the health care potential of bioactive compounds, J Sci Food Agric 86, 1805-1813.

Hossain, MA; Salehuddin, SM; Kabir, MJ; Rahman, SM; Rupasinghe, HV (2009) Sinensetin, rutin, 3'-hydroxy-5, 6, 7, 4'-tetramethoxyflavone and rosmarinic acid contents and antioxidative effect of the skin of apple fruit. Food Chem 113, 185-190.

Jesus, OP; Yahia, EM (2003) Postharvest hot air treatmentseffct on avocado fruit quality, chilling injury and triglycerides and tocopherols content. Acta Horticulture 604, 709-713.

Jouki, M; Khazaei, N (2012) The Effect of Modified Atmosphere Packaging and Calcium Chloride Dripping on the Quality and Shelf Life of Kurdistan Strawberries. Journal of Food Processing and Technology 3, 184.

Kader, AA; Zagory, D; Kerbel, EL (1989) Modified atmosphere packaging of fruits and vegetables. Crit Rev Food Sci Nutr 28, 1-30. 
Kang, GZ; Li, GZ; Liu, GQ; Xu, W; Peng, XQ; Wang, CY; Zhu, YJ; Guo, TC (2013) Exogenous salicylic acid enhances wheat drought tolerance by influence on the expression of genes related to ascorbateglutathione cycle. Biol Plant 57, 718-724.

Karuppanapandian, T; Moon, JC; Kim, C; Manoharan, K; Kim, W (2011). Reactive oxygen species in plants: their generation, signal transduction, and scavenging mechanisms. Aust J Crop Sci 5, 709725.

Kato-Noguchi, H; Watada, AE (1997) Citric acid reduces the respiration of fresh-cut carrots. HortScience 32, 136.

Khademi, Z; Ershadi, A (2013) Postharvest Application of Salicylic Acid Improves Storability of Peach (Prunus persicacv. Elberta) Fruits. Intern $J$ of Agric and Crop Sci 5, 651-655.

Koushesh, M; Arzani, K; Barzegar, M (2016) Impact of postharvest calcium treatments on storage life, biochemical attributes and chilling injury of apricot," Journal of Agricultural Science \& Technology 18 1355-1366.

Kulkarni, M; Borse, T; Chaphalkar, S (2007) Anatomical variability in Grape (Vitis venifera) Genotypes in Relation to Water Use Efficiency (WUE). American J Plant Physiol 2, 36-43.

Lafuente, T; Zacarias, L; Martı, MA; SanchezBallesta, T; Granell, A (2003) Phenylalanine ammonia-lyase and ethylene in relation to chilling injury as affected by fruit age in citrus. Postharvest Biology and Technology 29, 308-317.

Landjeva, S; Neumann, K; Lohwasser, U; Borner, A (2008) Molecular mapping of genomic regions associated with wheat seedling growth under osmotic stress. Biologia Plant 52, 259-266.

Leslie, CA; Romani, RJ (1988) Inhibition of ethylene biosynthesis by salicylic acid Plant Physiol 88, 833837.

Lu, X; Sun, D; Li, Y; Shi, W; Sun, G (2011) Pre- and Post-harvest salicylic acid treatments alleviate internal browning and maintain quality of winter pineapple fruit. Sci Hortic 130, 97-101

Maghenzani, M; Chiabrando, V; Giacalone, G (2016) The effect of different MAP on quality retention of fresh-cut nectarines. International Food Research Journal 23, 1872-1878.
Mahajan, BV; Kumar, D; Dhillon, WS (2013) Effect of different polymeric films on the shelf life and quality of pear fruits under supermarket conditions. Indian Journal of Horticulture 70, 309-312.

Meher, PS; Ashok, RK; Manohar, RD (2018) Effect of PEG-6000 imposed drought stress on RNA content, relative water content (RWC) and chlorophyll content in peanut leaves and roots Saudi J Biol Sci 25, 285-289.

Mirdehghan, SH; Rahemi, M; Martnez-Romero, D; Valverde, JM; Zapata, PJ; Serrano, M; Valero, D (2007) Reduction of pomegranate chilling injury during storage after heat treatment: role of polyamines. Postharvest Biol Technol 44, 19-25.

Mohamed, MA; AbdEl-khalek, AF; Elmehrat, HG; Gehan Mahmoud, A (2016) Pre-storage application of antioxidant alleviates chilling injury and maintains quality of Valencia orange fruits stored at low temperature. Egyptian Journal of Horticulture 43, 175193.

Mohammadi, H; Hanafi, Q (2014) Effect of different atmospheres on quality changes of Kurdistan strawberry. J Food Chem Nutr 2, 61-69.

Moretti, CL; Mattos, LM; Machado, CMM; Kluge, RA (2007) Physiological and quality attributes associated with different centrifugation times of baby carrots. Horticultura Brasileira 25, 557-561.

Neelma, MU; Faheem, AF (2009) The role of polyethylene glycol (PEG) pretreatment inimproving sugarcane's salt $(\mathrm{NaCl})$ tolerance. Turk J Bot 33, 407-415.

Nielsen, T; Leufven, A (2008) The effect of modified atmosphere packaging on the quality of Honeoye and Korona strawberries. Food Chemistry 107, 1031063.

Oliveira, A; Alexandre, EM; Coelho, M; Gomes, MH; Almeida, DP; Pintado, M (2015) Effect of modified atmosphere on poly-phenols during storage of pasteurised straw-berry purees. Food Science and Technology 60, 377-384.

Patade, VY; Bhargava, S; Suprasanna, P (2012) Effects of $\mathrm{NaCl}$ and iso-osmotic PEG stress on growth, Osmolytes accumulation and antioxidant defense in cultured sugarcane cells. Plant Cell Tissue Organ Cult 108, 279-286.

Ragab, MM (2002) Effect of spraying urea, ascorbic acid and NAA on fruiting of Washington Navel orange trees. M.Sc. thesis, Faculty of Agriculture, Minia University Egypt. 


\section{Synergistic Effect of Some Post-harvest Treatments and Passive Modified Atmosphere Packaging Conditions on Cold Storability of "Canino "Apricot Fruits}

Rao, MV; Koch, JR; Davis, KR (2000) Ozone: a tool for probing programmed cell death in plants. Plant Mol Biol 44, 346-358.

Santos-Diaz, MS; Ochoa-Alejo, AN (1994) Effect of water stress on growth, osmotic potential and solute accumulation in cell cultures from chili pepper (amesophyte) and creosote bush (axerophyte). Plant Sci 96, 21-29.

Satraj, A; Masud, T; Abbasi, KS; Mahmood, T; Ali, A (2013) Effect of different concentrations of salicylic acid on keeping quality of apricot cv. Habi at ambient storage. Journal of Biological and Food Science Research 2, 66-78.

Sen, A; Alikamanoglu, S (2013) Antioxidant enzyme activities, malondialdehyde and total phenolic content of PEG-induced hyperhydric leaves in sugar beet tissue culture. In Vitro Cell Dev Biol Plant 49, 396-404.

Sharma, P; Jha, AB; Dubey, RS; Pessarakli, M (2012) Reactive oxygen species, oxidative damage, and antioxidative defense mechanism in plants under stressful conditions. J Bot pp 217-037.

Shazly, SM; Eisa, AM; Moatamed, AM; Kotb, HR (2013) Effect of some agrochemical pre harvest foliar application on yield and quality of Swelling peach trees. Alexander J Agric Res 58, 219-229.

Shehata, SA; Emam, MS; Abou EL-Wafa, SM (2009) Effect of active and passive modi-fied atmosphere packaging on the quality at-tributes of Strawberries. Annals of Agric Sci Moshtohor 48, 119-130.

Singh, SP; Rao, DV (2005) Quality assurance of papaya by shrink film wrapping during storage and ripening. Journal of Food Science and Technology 42, 523-525.

Solis-Solis, HM; Calderon-Santoyo, M; GutierrezMartinez, P; Schorr-Galindo, S; Ragazzo-Sanchez, JA (2007) Discrimination of eight varieties of apricot (Prunus armeniaca) by electronic nose, LLE and
SPME using GC/MS and multivariate analysis. Sensors and Actuators, B: Chemical 125, 415-421.

Son, SM; Moon, KD; Lee, CY (2001) Inhibitory effects of various antibrowning agents on apple slices. Food Chem 73, 23-30.

Steel, RG; Torrie, JH; Dickey, Q (1997) Principles and Procedures of Statistics. A Biometrical Approach $3^{\text {rd }}$ Ed. McGraw Hill Book Co. Inc New York, USA.

Sweeney, MD; Zina, CV; Delesha, MC; Samuel, KL (2018) Physician Awareness of Immune Responses to Polyethylene Glycol-Drug Conjugates. Clinical and Translational Science 11, 162-165.

Tareen, MJ; Abbasi, NA; Hafiz, IA (2012) Postharvest application of salicylic acid enhanced antioxidant enzyme activity and maintained quality of peach cv. 'Flordaking' fruit during storage. ScientiaHorticulturae 142, 221-228

Wang, L; Chen, S; Kong, W; Li, S; Archbold, DD (2006) Salicylic acid pretreatment alleviates chilling injury and affects the antioxidant system and heat shock proteins of peaches during cold storage. Postharvest Biol Technol 41, 244-251.

Wellburn, AR (1994) The spectral determination of chlorophylls aand b, as wellas total carotenoids, using various solvents with spectrophotometers of different resolution. Journal of Plant Physiology 144, 307-313.

Wenande, E; Garvey, LH (2016) Immediate-type hypersensitivity to polyethylene glycols: a review". Clinical \& Experimental Allergy 46, 907-922.

Xu, X; Tian, S (2008) Salicylic acid alleviated pathogen-induced oxidative stress in harvested sweet cherry fruit. Postharvest Biol Technol 49, 379-385.

Yoruk, IH; Demir, H; Ekici, K; Sarvan, A (2005) Purification and properties of catalase from Van Apple (Golden Delicious). Pak J Nutr 4, 8-11. 
مجلة اتحاد الجامعات العربية للعلوم الزراعية، جامعة عين شمس، القاهرة، مصر مجلد(28)، عدد(4)، 1244-1225، 2020

التأثير المزدوج لبعض معاملات ما بعد الحصاد وتعديل الجو الهوائي سلبيا للعبوة على القدرة التخزينية لثمار المشمش الكانينو المبردة لفعايل

سماح إبراهيم نصر"

المعهد العالي للتعاون الزراعي - ص.ب. 198 حدائق شبرا - القاهرة - دصر

*Corresponding author: Samah55adel@yahoo.com

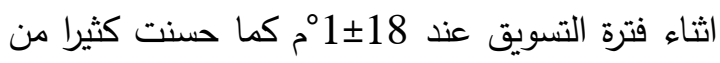
جودة الثمار مثل زيادة قيم المواد الصلبة الذائبة الكلية،

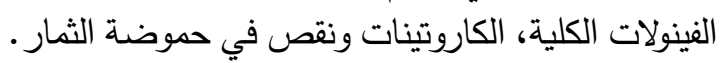
وكذلك تقليل معدل الفقد في حمض الأسكوربيك. ايضاً

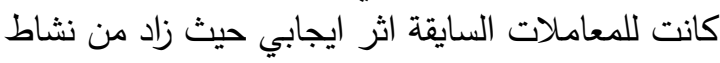

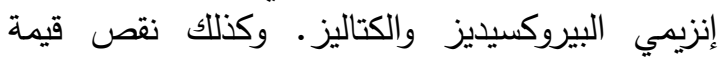
التوصيل الالكتروليني ومعدل التبنيل والتفس وعاليز وكامة فإن تقليل كلاً من أضرار البرودة والتوصيل الالكتروليني ومعدل ولئل

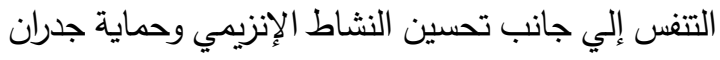

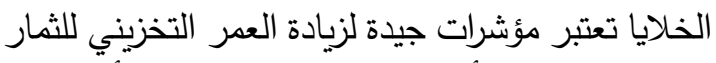

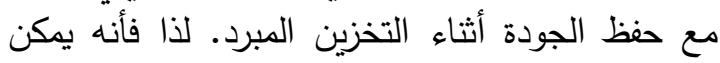

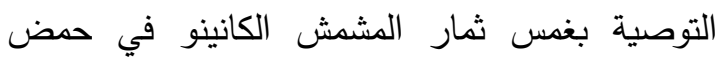

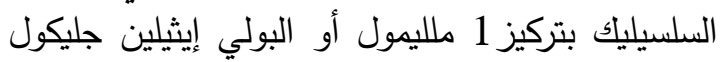
بتركيز 0.4\% مع التعبئة في عبول البول جو سلبي معدل

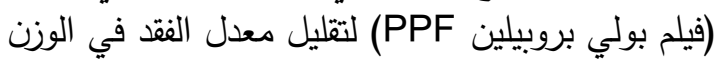

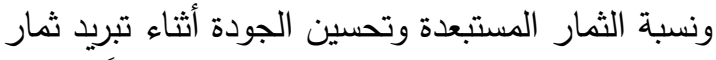

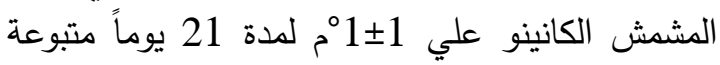

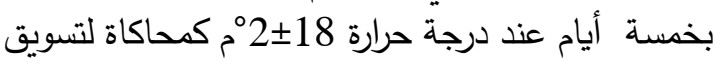

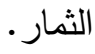

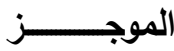

درس تأثير بعض معاملات ما بعد الحصاد مثل

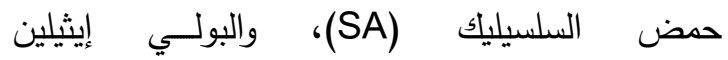

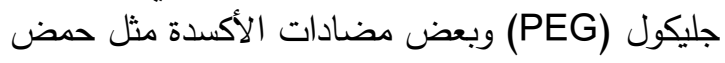

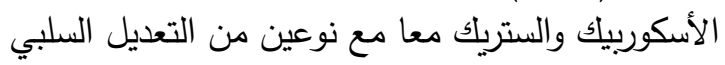

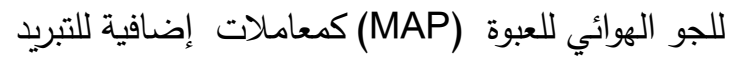

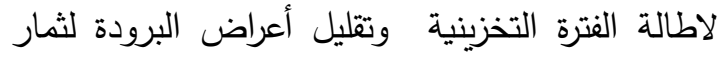

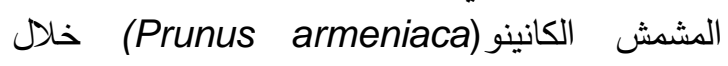

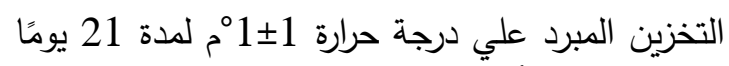

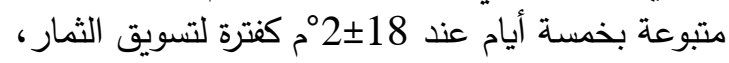
خلال موسمي 2018 \& \& 2019. وقد ت تم دراسة الصفات الطبيعية و الكيماوية والفسيولوجية خلال هذه وله

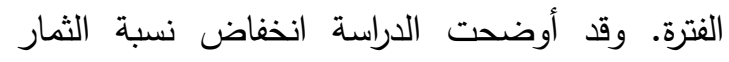

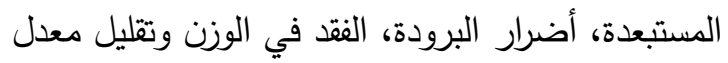

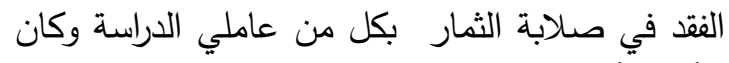

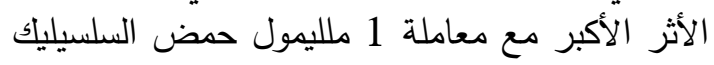
و0.4\% بولي إيثيلين جليكول مع النوع الثاني من التعديل

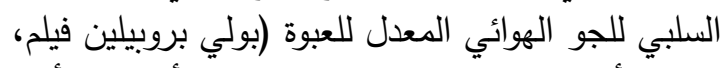

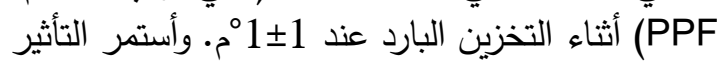

